\title{
司会の言葉
}

\author{
熊 谷 進*1 $・$ 品川邦 汎*2 \\ （*1国立感染症研究所食品衛生微生物部, *2岩手大学農学部)
}

\section{Symposium B The Sanitary Control of Food Materials Based on HACCP System}

\section{Introduction}

\author{
Susumu Kumagaya*1 and Kunihiro Shinagawa ${ }^{* 2}$ \\ ${ }^{* 1}$ The National Institute of Infectious Diseases, 1-23-1 Toyama, Shinjuku-ku, Tokyo 162) \\ (*2Department of Veterinary Microbiology, Faculty of Agriculture, Iwate University, \\ 3-18-8 Ueda, Morioka, Iwate 020)
}

HACCP 方式は，最終製品試験に頼らずに食品の安全 性を保証する衛生管理方式として開発されてきた方式で ある. 現在では我が国を含め国際的に広くその方式の有 効性が認識されつつあり, 各国において食品の生産者お よび製造者が自主的に，あるいは行政主導的に， HACCP方式の導入を計っていたり，既に実行してい る. 我が国においては, 厚生省が HACCP 方式による衛 生管理から成る「総合衛生管理製造過程」による製造の 承認制度を，まず乳・乳製品および肉製品の製造に導入 したところである。

HACCP 方式は, 7 つの原則である危害分析 (HA), 重 要管理点 $(\mathrm{CCP})$, 管理基準 $(\mathrm{CL})$, モニタリング, 改善措 置, 検証, 記録を基本要素とする衛生管理方法である. その方法がねらうところは, 衛生管理のポイントとなる 重要な管理点を連続的に監視することによって欠陥製品 を見逃すことなく確実に管理し，さらに，その管理点に おける監視事項が許容範囲を越えた場合にはただちに適 正な措置を講じることによって, 危害を招く可能性のあ る製品が流通に入り, 消費されることを未然に防止する ことにある。

HACCP 方式は, 食品の原材料の生産から, 最終製品 が消費者に消費されるまでの，すべての過程に適用する ことができるとされている. そのシステムの導入によっ て, 食品の安全性が向上することはむとより, 食糧資源
をより有効に利用できるようになること, 衛生上の危害 に適時対処できるようになること，行政による監視と指 導が効果的効率的に行なえるようになること, 食品の安 全性に関して国際的な信頼性が高まり，その結果として 食品の国際流通が促進されることなどが期待できる.

本シンポジゥムでは, 食品の原材料の生産から最終製 品が消費者に消費されるまでの食品の流れのうち, 特に 動物性食品およびその原材料の段階に焦点を当てて, HACCP 方式による衛生管理に関し，講演と討議をいた だいた. 笹野 貢先生 ((社) 北海道生乳検查協会)には, HACCP 方式との関わりにおける生乳の衛生管理におけ る現状と問題点, 仁科徳啓先生（静岡県衛生環境セン ター）には牛・豚処理工程への HACCP 方式導入に必要 な生肉（枝肉）の微生物制御，豊福 肇先生（国立公衆 衛生院）には水産食品への HACCP 方式導入の現状と HACCP 方式による衛生管理における問題点, 加地祥文 先生（厚生省）には今後の食品原材料の衛生管理におけ る HACCP方式との関連におけるキーポイントについ て，それぞれ貴重な知見をご提供いただくとともに今後 の問題点を提起していただいた. それらご講演および会 場からの活発なご意見やご提言をいただくことによっ て, 本シンポジウム参加者が動物性食品における HACCP 方式についてさらに理解を深めることができた とすれば，司会者として望外の喜びであります.

\footnotetext{
*1 俨162 新宿区戸山 1-23-1

*2 焉020 岩手県盛岡市上田 3-18-8
} 


\title{
生孚 \\ 笹 野 貢 \\ （北海道生乳検查協会）
}

\section{Symposium B The Sanitary Control of Food Materials Based on HACCP System}

\section{A Hygiene Quality Control of Raw Milk by HACCP System}

\author{
Mitsugu Sasano \\ (Hokkaido Milk Testing Association, North 3, West 7, Chuo-ku, Sapporo 060)
}

Key words: HACCP, Raw milk, Sanitary control

はじめに

厚生省は乳・乳製品と食肉製品に対し HACCPによ る製造承認制度を導入することとし，食品衛生法施行規 則等の一部改正を行い昨年 5 月 24 日から施行した。

これは食品の生産から消費までの間で，危害の原因を 特定 (危害分析, HA) し, その発生を未然に防止するた めの管理手続（重要管理点, CCP）を定めて監視するこ とである. 生乳の危害の特定については，乳質の実態や 製造の品目により色々の論議があるが，一般的には生乳 や乳・乳製品の規格である「原料牛乳の日本農林規格」 と「乳等省令の規格」が対象になると考える.

ここでは生乳の主な HACCP をとりあげ，北海道にお ける現状の乳質と問題点について述べる.

\section{危害の種類}

\section{1. 腐敗微生物}

乳等省令によると生乳の細菌数は，直接個体鏡検法 （以下直検法）で $1 \mathrm{~m} l$ 当たり 400 万以下之規定されてい る. 近年, 北海道における生乳の品質は, 生産者や酪農 関係者の努力により著しく改善が図られ，当協会の昭和 62 年度以降タンクローリー乳の検查でこの規格外生乳 の発生がみられない(表 1). 北海道乳質改善協議会では 昭和 61 年度にバルク乳の改善目標を 30 万 $/ \mathrm{m} l$ 以下と 定めたが，この基準でタンクローリ一乳の検査結果をみ ると昭和 61 年度 $79.9 \%$ であったものが平成元年度上 期 98.8\% に向上した．当協会では乳質の向上に伴い直 検法では低レベルの細菌数を的確に判定することが困難 であるとし，平成元年度下期からより精度の高い平板培 養法（生菌数）の一種であるスパイラル法を採用してい 焉060 北海道札幌市中央区北 3 条西 7 丁目
表 1 タンクローリー乳の細菌数検查結果

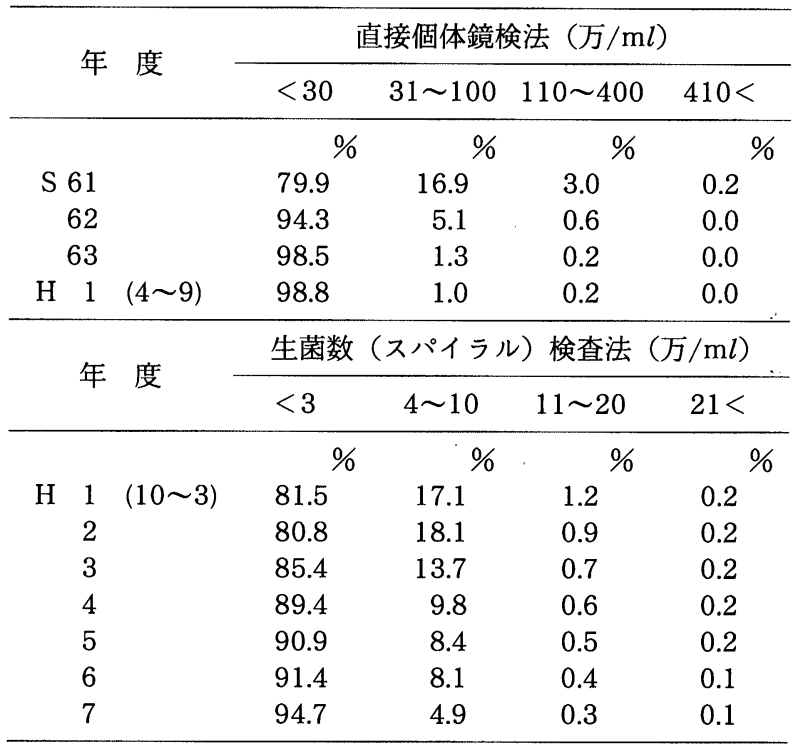

る. なお，直検法と平板培養法との菌数比率は $3 \sim 4: 1$ といわれている. 北海道乳質改善協議会では平成 6 年度 にバルク乳の改善目標を 3 万 $/ \mathrm{m} l$ 以下と定めており，こ の基準で平成 7 年度のタンクローリー乳の検查結果 ${ }^{1}$ を みると $94.7 \%$ となっている.

このように道内流通生乳であれば, 生菌数 3 万 $/ \mathrm{ml}$ 以 下（直検法 10 万 $/ \mathrm{m} l$ 以下に相当）が主体を占めるので, 乳等省令の 400 万 $/ \mathrm{m} l$ 基準の問題はすでにクリアして いるといえる。 しかし，本道から年間約 50 万 $\mathrm{t}$ の生乳 が関東, 中京, 関西の大消費地に向けて移出されており, この輸送に長時間（48～72 時間）要することから低温 細菌の増殖がさけられない実態にある。本道としてはバ ルク乳の改善目標を生菌数 1 万 $/ \mathrm{m} l$ 以下にして, 高品質 な生乳の確保を図る必要がある。 
表 2 バルク乳中の乳房炎起因菌 (Sa) スクリーニング検出結果

\begin{tabular}{|c|c|c|c|c|c|c|c|c|c|c|}
\hline \multirow{2}{*}{\multicolumn{2}{|c|}{ No. 地 }} & \multirow{2}{*}{ 域 } & \multirow{2}{*}{ 調査農家 } & \multirow{2}{*}{$\begin{array}{c}\text { Sa 菌 } \\
\text { 検出農家 }\end{array}$} & \multirow{2}{*}{ 検出率 } & \multicolumn{4}{|c|}{ 菌数レベル } & \multirow{2}{*}{ 調査年月 } \\
\hline & & & & & & 0 & $1 \sim 150$ & $151 \sim 250$ & $251<$ & \\
\hline & & & 戸 & 戸 & $\%$ & $/ \mathrm{m} l$ & $/ \mathrm{m} l$ & $/ \mathrm{m} l$ & $/ \mathrm{m} l$ & \\
\hline 1 & 道 & 北 & 8 & 4 & 50.0 & 4 & 4 & & & H 5.8 \\
\hline 2 & 道 & 南 & 6 & 4 & 66.7 & 2 & 2 & 1 & 1 & 6.5 \\
\hline 3 & 道 & 北 & 54 & 12 & 22.2 & 42 & 11 & & 1 & 6. 3 \\
\hline 4 & 道 & 南 & 6 & 5 & 83.3 & 1 & 4 & & 1 & 7.5 \\
\hline \multicolumn{3}{|c|}{$\begin{array}{c}\text { 計 } \\
\text { (平均) }\end{array}$} & 74 & 25 & (33.8) & $\begin{array}{c}49 \\
(66.2)\end{array}$ & $\begin{array}{c}21 \\
(28.4)\end{array}$ & $\begin{array}{c}1 \\
(1.4)\end{array}$ & $\begin{array}{c}3 \\
(4.0)\end{array}$ & \\
\hline
\end{tabular}

注 Sa: Staphylococcus aureus 菌数レベル：ミネソタ州立大学 Bulk tank mastitis screening report の基準

\section{2. 病原微生物}

食品衛生法の施行規則の一部改正する省令によると, 乳・乳製品には病原微生物として 6 種「Salmonella 属 菌, Staphylococcus aureus (Sa), Listeria monocytogenes (Lm), 病原大腸菌, Campylobacter jejuni/coli, Yersinia enterocolitica」が陰性でなければならないと規定してい る.

北海道では生乳の流通段階で，これらの検查を実施し ていない。しかし，当協会では Sa 菌は乳房炎防除対策 および Lm 菌は食中毒予防対策の立場上生産現場での 部分的な調查を実施してきた。

$\mathrm{Sa}$ 菌の検出率については, バルク乳の 4 地域の調 査 $^{2 \sim 5)}$ (表 2) で 22.2〜 83.3\% の範囲で平均 33.8\% であ り，地域によって污染度が異なることが分かった。 また， 検出菌数レベルはバルク乳 25 件中, $1 \sim 150 / \mathrm{m} l$ のもの 21 件, $151 \sim 250 / \mathrm{m} l$ のもの 1 件, $251 / \mathrm{ml}$ 以上のもの 3 件であった。

次に，道内 6 戸の農家について平成 6 年 5 月から 11 月までバルク乳のモニタリングを実施 ${ }^{3)}$ (表 3）したとこ
表 3 バルク乳中の乳房炎起因菌 (Sa) モニタリング検出結果

\begin{tabular}{|c|c|c|c|c|c|c|c|}
\hline 農家 & $\begin{array}{l}\mathrm{H} 6 \\
5 \text { 月 }\end{array}$ & 6 月 & 7 月 & 8 月 & 9 月 & 10 月 & 11 月 \\
\hline A & ${ }_{400}^{/ \mathrm{ml}}$ & $\begin{array}{c}/ \mathrm{ml} \\
126\end{array}$ & $\begin{array}{c}/ \mathrm{m} l \\
320\end{array}$ & $\begin{array}{l}/ \mathrm{m} l \\
6\end{array}$ & $/ \mathrm{m} l$ & $\begin{array}{l}/ \mathrm{m} l \\
6\end{array}$ & $\begin{array}{c}/ \mathrm{ml} \\
320\end{array}$ \\
\hline B & 200 & 13 & 13 & & 6 & & \\
\hline C & & 6 & 6 & 6 & & & \\
\hline D & 26 & 6 & 20 & & 26 & & \\
\hline $\mathrm{E}$ & 6 & & 6 & & & & \\
\hline F & & 6 & & & & & \\
\hline Sa 菌 & & & & & & & \\
\hline $\begin{array}{c}\text { 検出農家 } \\
\text { (户) }\end{array}$ & 4 & 5 & 5 & 2 & 2 & 1 & 1 \\
\hline
\end{tabular}

ろ感染牛の早期乾乳期治療, 多分房感染牛の淘汰, 別搾 乳による新規感染防止等に努めた結果, 1 農家 $(\mathrm{A})$ を除 き 10 月以降 Sa 菌の検出がなくなり清浄化が図られた. さらに, 6 戸が飼養する個体牛について, 平成 6 年 $5 \sim 6$ 月と 9 10月の 2 回 $\mathrm{Sa}$ 菌の検出調査 ${ }^{3)}$ (表 4) したとこ ろ，1 回目は 180 頭， 711 分房中 $\mathrm{Sa}$ 菌が検出されたも

表 4 個体分房乳中の乳房炎起因菌 $(\mathrm{Sa})$ 検出結果

\begin{tabular}{|c|c|c|c|c|c|c|c|c|}
\hline \multirow{3}{*}{ 農 家 } & \multicolumn{4}{|c|}{ 第 1 回 (H6. 5〜6) } & \multicolumn{4}{|c|}{ 第 2 回 (H 6.9〜10) } \\
\hline & \multirow{2}{*}{ 頭 数 } & \multirow{2}{*}{ 分房数 } & \multicolumn{2}{|c|}{ Sa 菌 } & \multirow{2}{*}{ 頭 数 } & \multirow{2}{*}{ 分房数 } & \multicolumn{2}{|c|}{$\mathrm{Sa}$ 菌 } \\
\hline & & & 頭 数 & 分房数 & & & 頭 数 & 分房数 \\
\hline $\begin{array}{c}A \\
(\%)\end{array}$ & 36 & 142 & $\begin{array}{c}15 \\
(41.7)\end{array}$ & $\begin{array}{c}26 \\
(18.3)\end{array}$ & 33 & 130 & $\begin{array}{c}12 \\
(36.4)\end{array}$ & $\begin{array}{c}12 \\
(9.2)\end{array}$ \\
\hline B & 33 & 129 & 2 & 3 & 15 & 60 & 0 & 0 \\
\hline (\%) & & & ( 6.1$)$ & ( 2.3) & & & $(0.0)$ & $(0.0)$ \\
\hline $\begin{array}{c}\mathrm{C} \\
(\%)\end{array}$ & 37 & 147 & $\begin{array}{c}0 \\
(0.0)\end{array}$ & $\begin{array}{c}0 \\
(0.0)\end{array}$ & 17 & 68 & $\begin{array}{c}0 \\
(0.0)\end{array}$ & $\begin{array}{c}0 \\
(0.0)\end{array}$ \\
\hline $\begin{array}{c}D \\
(\%)\end{array}$ & 30 & 120 & $\begin{array}{c}2 \\
(6.7)\end{array}$ & $\begin{array}{c}2 \\
(16.7)\end{array}$ & 14 & 53 & $\begin{array}{c}0 \\
(0.0)\end{array}$ & $\begin{array}{c}0 \\
(0.0)\end{array}$ \\
\hline $\begin{array}{c}\mathrm{E} \\
(\%)\end{array}$ & 30 & 119 & $\begin{array}{c}2 \\
(6.7)\end{array}$ & $\begin{array}{c}3 \\
(2.5)\end{array}$ & 10 & 37 & $\begin{array}{c}0 \\
(0.0)\end{array}$ & $\begin{array}{c}0 \\
(0.0)\end{array}$ \\
\hline $\begin{array}{c}F \\
(\%)\end{array}$ & 14 & 54 & $\begin{array}{c}0 \\
(0.0)\end{array}$ & $\begin{array}{c}0 \\
(0.0)\end{array}$ & 5 & 20 & $\begin{array}{c}0 \\
(0.0)\end{array}$ & $\begin{array}{c}0 \\
(0.0)\end{array}$ \\
\hline $\begin{array}{l}\text { 計 } \\
(\%)\end{array}$ & 180 & 711 & $\begin{array}{c}21 \\
(11.7)\end{array}$ & $\begin{array}{c}34 \\
(4.8)\end{array}$ & 94 & 368 & $\begin{array}{c}12 \\
(12.8)\end{array}$ & $\begin{array}{c}12 \\
(3.3)\end{array}$ \\
\hline
\end{tabular}

注 道南地域調查

第 1 回 全搾乳牛調査 第 2 回 $\mathrm{A}$ 農家は全搾乳牛, 他の農家は第 1 回以降分婏牛および農家の希望する高体細胞数牛 
表 5 バルク乳中の Listeria monocytogenes $(\mathrm{Lm})$ 検出結 果

\begin{tabular}{|c|c|c|c|c|}
\hline 農 協 & 調查農家 & 検出農家 & 検出率 & 調查年月 \\
\hline & 戸 & 戸 & $\%$ & \\
\hline A & 57 & 10 & 17.5 & H 7.11 \\
\hline B & 20 & 2 & 10.0 & 7. 11 \\
\hline $\mathrm{C}$ & 44 & 9 & 20.5 & 8. 2 \\
\hline 計（平均） & 121 & 21 & 17.4 & \\
\hline
\end{tabular}

表 6 バルク乳 2 回連続検查の Listeria monocytogenes $(\mathrm{Lm})$ 検出結果

\begin{tabular}{ccc}
\hline 区 分 & 農家戸数 & 検出率 \\
\hline & \multicolumn{2}{c}{ 戸 } \\
2 回連続陽性 & 9 & 20.5 \\
1 回陽性 & 5 & 11.4 \\
2 回連続陰性 & 30 & 68.1 \\
\hline \multicolumn{1}{c}{ 計 } & 44 & 100.0 \\
\hline
\end{tabular}

表 7 東テネシーおよび南西バージニアのバルク乳中の病 原微生物の検出結果

\begin{tabular}{lccc}
\hline \multicolumn{1}{c}{ 区 分 } & 農家戸数 & 検出戸数 & 検出率 \\
\hline & 戸 & 戸 & $\%$ \\
L. monocytogenes & 292 & 12 & 4.1 \\
C. jejuni & 292 & 36 & 12.3 \\
Y. enterocolitica & 292 & 44 & 15.1 \\
Salmonella & 292 & 26 & 8.9 \\
\hline
\end{tabular}

(B. W. Rohrbach ら, 1990 調查)

の 21 頭 (頭数比率 11.7\%), 34 分房 (分房数比率 4.8\%）であり 2 回目は 94 頭, 368 分房中 $\mathrm{Sa}$ 菌が検出 されたのは $\mathrm{A}$ 農家しかなかったが 12 頭（頭数比率 12.8\%)，12 分房（分房数比率 3.3\%）であった. A 農家 の原因を究明したところ牛舎の構造と搾乳手順に問題が あることが判明した。

Lm 菌の検出率については, バルク乳の 3 地域の調査 （表 5）で 10.0 20.5\% の範囲で平均 $17.4 \%$ であった. また, バルク乳の 2 回連続出荷時における Lm 菌の污染 率を調查（表 6）したところ，44 戸中 2 回連続して陽性 だった農家 9 戸 (20.5\%), 1 回だけ陽性農家 5 戸 (11.4\%)，2 回とも陰性だった農家 30 戸 (68.1\%) であ
り，Lm 菌が毎日検出されるあのではないと考える. Lm 菌の污染原因を調べたところ, pH の高い発酵不良のサ イレージに増殖しており，これを牛に給与することによ り糞便が乳房や敷料を污染し, 最終的に生乳に混入する あのである.

その他の病原微生物による生乳污染についてのデー夕 は，道内および国内に少ないので外国の例でみると B.

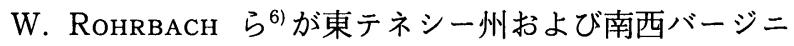
ア州のバルク乳を調查 (表 7) したところ，292 戸中 Lm 12 戸 (4.1\%) Campylobacter jejuni 36 戸 (12.3\%), Yersinia enterocolitica 44 戸 (15.1\%), Salmonella 26 戸 (8.9\%) が検出され， 1 種類以上検出されたものは 95 戸 (32.5\%) ああったと報告している.

今回指定された 6 種の病原微生物は, いずれも自然界 に広く分布したり, 乳牛の消化器に生息したりするの で，生乳の生産現場で “0” とすることは極めて非現実的 である。しかし，放置しておくと生産性の低下や食中毒 の原因となるので, 目標レベルを設定して定期的な検查 （年間ベース）を実施するとともに生産現場では衛生的 な搾乳手順の徹底や定期的な牛舎消毒の励行など搾乳衛 生環境の改善を早急に図ることが肝要と考える.

\section{3. 異常乳成分}

原料乳の日本農林規格によると生乳の脂肪率 $2.8 \%$ 未 満は 2 等乳と格付けされる. また, 乳等省令によると牛 乳の成分規格は脂肪率 $3.0 \%$ 以上，無脂固形分率 $8.0 \%$ 以上と規定されている. 北海道における当協会の平成 7

表 8 タンクローリー乳の成分検查結果

\begin{tabular}{|c|c|c|c|c|}
\hline 年 & 度 & 脂肪率 & 蛋白質率 & 無脂固形分率 \\
\hline \multirow{3}{*}{ S } & & $\%$ & $\%$ & $\%$ \\
\hline & 61 & 3.71 & 3.02 & 8.58 \\
\hline & 63 & 3.74 & 3.07 & 8.61 \\
\hline \multirow[t]{4}{*}{$\mathrm{H}$} & 1 & 3.76 & 3.11 & 8.57 \\
\hline & 3 & 3.79 & 3.14 & 8.63 \\
\hline & 5 & 3.89 & 3.12 & 8.60 \\
\hline & 7 & 3.88 & 3.18 & 8.65 \\
\hline \multicolumn{2}{|c|}{ 参考 } & & & \\
\hline \multicolumn{2}{|c|}{ 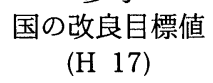 } & 3.8 & 3.4 & 8.8 \\
\hline
\end{tabular}

表 9 バルク乳の年度別成分規格外の発生率

\begin{tabular}{|c|c|c|c|c|c|c|}
\hline \multirow{2}{*}{ 年 度 } & \multirow{2}{*}{ 㭘体数 } & \multicolumn{3}{|c|}{ 脂肪率 (\%) } & \multicolumn{2}{|c|}{ 無脂固形分率 (\%) } \\
\hline & & $<2.8$ & $<3.0$ & $<3.5^{*}$ & $<8.0$ & $<8.3^{*}$ \\
\hline & & $\begin{array}{r}\text { 件 } \\
(\%)\end{array}$ & $\begin{array}{r}\text { 件 } \\
(\%)\end{array}$ & $\begin{array}{r}\text { 件 } \\
(\%)\end{array}$ & $\begin{array}{r}\text { 件 } \\
(\%)\end{array}$ & $\begin{array}{r}\text { 件 } \\
(\%)\end{array}$ \\
\hline 5 & 497,544 & $\begin{array}{c}0 \\
(0.00)\end{array}$ & $\begin{array}{c}202 \\
(0.04)\end{array}$ & $\begin{array}{c}18,401 \\
(3.70)\end{array}$ & $\begin{array}{l}1,926 \\
(0.39)\end{array}$ & $\begin{array}{c}23,839 \\
(4.79)\end{array}$ \\
\hline 6 & 527,636 & $\begin{array}{c}2 \\
(0.00)\end{array}$ & $\begin{array}{c}188 \\
(0.04)\end{array}$ & $\begin{array}{c}23,993 \\
(4.55)\end{array}$ & $\begin{array}{l}1,883 \\
(0.36)\end{array}$ & $\begin{array}{c}25,306 \\
(4.80)\end{array}$ \\
\hline 7 & 526,899 & $\begin{array}{c}0 \\
(0.00)\end{array}$ & $\begin{array}{c}141 \\
(0.03)\end{array}$ & $\begin{array}{c}20,159 \\
(3.80)\end{array}$ & $\begin{array}{l}1,522 \\
(0.29)\end{array}$ & $\begin{array}{c}17,809 \\
(3.38)\end{array}$ \\
\hline
\end{tabular}

注 *: 飲用原料乳の取引基準値

（北海道乳質改善協議会調） 
年度タンクローリー乳の検査結果 ${ }^{1)}$ (表 8) によると, 年 間平均值は脂肪率 3.88\%, 無脂固形分率 8.65\% であり, タンクローリー路線別最低值は脂肪率 $3.40 \%$, 無脂固形 分率 $8.10 \%$ であり, 取引段階では異常成分の規格外生 乳の発生がみられない.

なお，平成 17 年度国の家畜改良目標による之，脂肪 率 3.8\%, 無脂固形分率 8.8\%, 蛋白質率 3.4\% と設定し ており,これを 7 年度の検査結果でみると, 脂肪率はす でに目標値に到達しているものの, 無脂固形分率で約 $0.1 \%$, 蛋白質率で $0.2 \%$ の改善を図る必要がある.

北海道乳質改善協議会の平成 7 年度バルク乳の検查 結果（表 $9, n=526,899 ）$ によると脂肪率 $2.8,3.0 \%$ 以下 の比率は，それぞれ $0,0.03 \%$ であり，無脂固形分率 $8.0 \%$ 以下の比率は $0.29 \%$ であった. 規格外生乳発生の 主因は，パイプラインミルカー操作の間違いにより水が 混入するためである. 低成分乳に対する水点検查の励行 と生産者に対する適正な搾乳機器管理技術の指導が望ま
れる.

\section{4. 抗菌性物質}

乳等省令によると生乳は抗菌性物質を含有してはなら ないと規定されている. 北海道では昭和 56 年度に北海 道農務部長および衛生部長から, 生乳のより一層の安全 性を確保するため従来の TTC 法に加えてより精度の高 いペーパーディスク法（ペニシリン感度 $0.005 \mathrm{IU} / \mathrm{ml}$ ) を採用し, 乳業工場における受入タンクローリー乳の検 查の励行, タンクローリ一乳で陽性となった場合の追跡 用バルク乳試料の採取・保管の義務付け, タンクロー リー乳やバルク乳で陽性となった場合の対応（図 1）お よび抗菌性物質を使用した個体分房乳の出荷前確認検查 の励行などを内容とする通達畐が出された.

平成 $3 \sim 7$ 年度の 4 力年間に道内で発生した乳業工場 到着時のタンクローリー陽性乳は 15 件（表 10）であっ た. 現行のペーパーディスク法では検査に 3 時間以上か かるため, タンクローリー乳はストレージタンクに入り

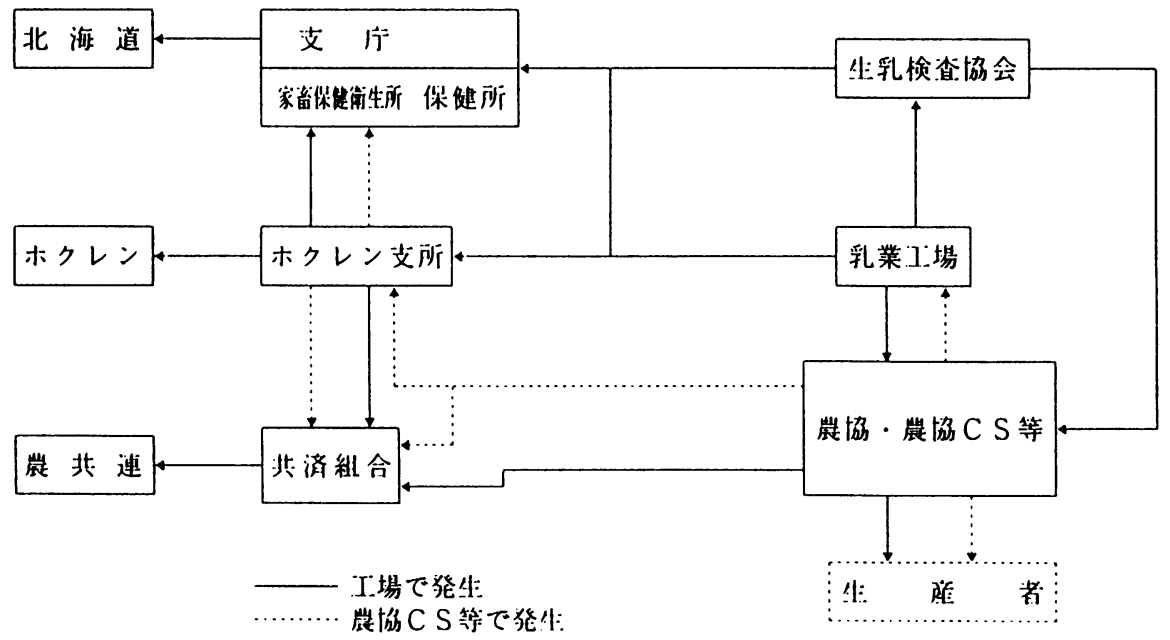

図 1 陽性乳が発生した場合の対応

表 10 乳業工場受入時の抗菌性物質残留乳の発生状況

\begin{tabular}{|c|c|c|c|c|c|c|c|c|}
\hline \multirow{2}{*}{ No. } & \multirow{2}{*}{ 地 } & \multirow{2}{*}{ 域 } & \multirow{2}{*}{ 発生年月 } & \multirow{2}{*}{ 廃棄乳量 } & \multirow{2}{*}{$\begin{array}{l}\text { 該当タンク } \\
\text { ローリー乳量 }\end{array}$} & \multicolumn{3}{|c|}{ 発 生 原 因 } \\
\hline & & & & & & 治療牛の識別不徹底 & 確認検查の未受検 & 不 明 \\
\hline & & & & $t$ & $\mathrm{t}$ & & & \\
\hline 1 & 道 & 北 & $\mathrm{H} 3.11$ & 131.4 & 9.7 & 0 & & \\
\hline 2 & 道 & 東 & $\mathrm{H}$ 4. 2 & 115.2 & 11.0 & & & $\bigcirc$ \\
\hline 3 & 道 & 東 & 4 & 43.2 & 8.8 & 0 & & \\
\hline 4 & 道 & 東 & 8 & 38.9 & 9.2 & & 0 & \\
\hline 5 & 道 & 東 & 9 & 19.5 & 3.5 & 0 & & \\
\hline 6 & 道 & 南 & 10 & 43.9 & 9.0 & & 0 & \\
\hline 7 & 道 & 東 & H 5. 6 & 11.4 & 8.9 & & 0 & \\
\hline 8 & 道 & 東 & 11 & 108.0 & 6.0 & 0 & & \\
\hline 9 & 道 & 南 & 12 & 20.3 & 4.7 & 0 & & \\
\hline 10 & 道 & 東 & H 6.2 & 115.2 & 6.7 & 0 & & \\
\hline 11 & 道 & 南 & 5 & 71.8 & 9.1 & & & 0 \\
\hline 12 & 道 & 北 & 8 & 261.4 & 9.4 & 0 & & \\
\hline 13 & 道 & 北 & 10 & 274.8 & 8.7 & 0 & & \\
\hline 14 & 道 & 南 & H 7.12 & 50.0 & 9.7 & 0 & & \\
\hline 15 & 道 & 東 & H 8.1 & 10.4 & 9.7 & 0 & & \\
\hline & 合 & & & $1,315.4$ & 124.1 & 10 & 3 & 2 \\
\hline & F & & & 87.7 & 8.3 & & & \\
\hline
\end{tabular}


検查結果を待つことになる。むし陽性と判明するとスト レージタンク乳全量を生産者サイドの負担で廃棄するこ とになる。したがって, 当該タンクローリ一乳は平均 $8.3 \mathrm{t}$ であったが, 実際の廃棄乳量は $10.4 \sim 274.8 \mathrm{t}$ の範 囲で平均 $87.7 \mathrm{t}$ にも達している.

しかし，道内の乳業工場では全受入タンクローリー乳 の検査を完全に実施しているので，製造ラインに陽性乳 が混入することはない.

陽性乳発生の主因は，抗生物質治療牛の識別を明確に せず誤って治療牛の乳を出荷したり, 残留確認検查を受 けずにあう出荷してあ良いだろうとの素人判断によるあ のである. 陽性乳の出荷は, 他人の生乳を污染するばか りか, 酪農経営が不可能になるほどの大きな被害を受け るので，生産者の十分な注意が必要である.

\section{5. 洗剂および殺菌剂}

乳等省令によると牛乳・乳製品には洗剤および殺菌剂 か残留または混入してはならないと規定されている，洗 剤および殺菌剤の生乳への混入は, パイプラインミル カーやバルククーラーの洗浄・殺菌の不適，ディッピン グの不適などである．パイプラインミルカーやバルク クーラーの保守管理上洗剤・殺菌剤は欠かせないあので あるが，その使用後には必ず十分な水すすぎをして，こ れらの成分が機器表面に残留しないよう指導している. ただし，次亜塩酸ナトリウム単用は，毒性上から多少食 品に混入しても無害なあのとして, 食品衛生法上で食品 添加物合成殺菌剤として認められているので，きれいな 水が得られない場合は水すすぎを省略することができ る。また，ディッピングはヨウ素剤が多いが，適正な濃 度での使用や控乳前の乳頭表面からヨウ素を十分拭き取 るよう指導している.

生乳中の洗剂・殺菌剤の検出法は，官能検查法による しかなく，現在のところ特に問題となっていない，しか し, 今後は官能検查技術のレベルアップや新しい迅速検 查法の開発が期待される。

\section{6. 塵埃・その他異物}

原料乳の日本農林規格によると生乳には塵埃・その他 異物を含んではならないと規定されている，また，乳等 省令によると牛乳・乳製品には異物を含んではならない と規定されている.

塵埃の生乳への混入は，主としてミルカーの誤操作に より牛床や牛体の塵埃の吸引による。農家における生乳 の塵埃の除去はパイプラインミルカーではインライン フィルターにより, バケットミルカーではバルククーラ 上に置くろ過器による，農家には塵埃ろ過の徹底は当然 であるが，基本的に生乳に塵埃を入れないよう指導して いる. 生乳の塵埃（セジメント）検查は細菌との関連で 缶輸送時代に必須項目として実施されたが, 細菌数レ心゙
ルが大幅に低下した今日，定期的に実施しなくても特に 問題となっていない.

その他異物としては飼料や飲用水を通して生乳に移行 する農薬, 放射性核物質, PCB (塩化ビフェニール), 重 金属 (カドニゥムなど), 発癌性物質（アフラトキシンな ど）があり，㩁乳以降生乳に添加または混入される異種 食品成分（異種脂肪，異種蛋白質）などがある。

現在これら異物の定期的な検查は実施していないが， 過去の部分的な調查 ${ }^{8}$ で検出されておらず，特に問題之 なっていない，しかし，消費者の食品公害物質への関心 が高まりつつあるなかで，これら物質が生乳に混入の恐 れが生ずる場合には緊急的に検查をする必要がある.

\section{おわりに}

生乳の生産段階における HACCP 方式は工場という 閉鎖された空間で対応できる加工・製造と異なって，畜 舎・ミルキングパーラーなど開放された空間での対応と なるため, 安全性に関する要因が多く，かつ互いに絡み 合っているので極めて複雑である。全国牛乳協会9 では 牛乳の原料である生乳について，HACCP のガイドライ ンを示しており，今後はチーズなど製品別のガイドライ ンあ必要となろう。いずれにせよ，乳・乳製品の原料で ある生乳の衛生的対策を系統化し, 総合的な生乳衛生管 理体系を早急に構築することが必要と考える。

\section{文献}

1）北海道生乳検查協会: 平成 7 年度事業成績書, $20,35-37$ (1996).

2）北海道生乳検查協会：平成 5 年度 JA 北見枝幸高品質生 乳生産供給指導事業報告書, 11 (1994).

3）北海道生乳検查協会：平成 6 年度 JA 長万部町高品質生 乳生産供給指導事業報告書, 26-27 (1995).

4）北海道生乳検查協会: 平成 6 年度 JA 雄信内高品質生乳 生産供給指導事業報告書, 51-52 (1995).

5) 北海道生乳検查協会：平成 7 年度 JA 今金町高品質生乳 生産供給指導事業報告書, 17 (1996).

6) Rohrbach, B. W., Drughon, F. A., Davidson, P. M. and Oliver, P.: Prevalence of Listeria monocytogenes, Campylobacter jejuni, Yersinia enterocolitica, and Salmonella in bulk tank milk, J. Food Prot., 55(2), 9397 (1992).

7）北海道農務部酪農草地課：酪農事業施設等関係通達集, 75-90 (1986).

8）笹野 貢：北海道に打ける原料乳質の変遷，Japanese Journal of Dairy and Food Science, 35(5), A185-A198 (1986).

9）全国牛乳協会：HACCP システムに基づく総合衛生管理 製造過程制度に係る講習会資料 II (マニュアル編), 136-137 (1997). 


\author{
食 \\ 肉 \\ 仁科徳 啓*1 ・品川邦沉*2 \\ (*1静岡県衛生環境センター, *2岩手大学農学部)
}

\title{
Symposium $B$
}

The Sanitary Control of Food Materials Based on HACCP System

\section{A Hygiene Quality Control of Fresh Meat by HACCP System}

\author{
Tokuhiro NishinA ${ }^{* 1}$ and Kunihiro Shinagaw ${ }^{* 2}$ \\ ${ }^{* 1}$ Shizuoka Prefectural Institute of Public Health and Environmental \\ Science, 4-27-2 Kitaando, Shizuoka 420) \\ (*2Department of Veterinary Microbiology, Faculty of Agriculture, \\ Iwate University, 3-18-8 Ueda, Morioka, Iwate 020)
}

Key words: Sanitary quality control, Meat, HACCP, Beef slaughter, Pork slaughter

はじめに

安全で衛生的な食肉を提供するためには，家畜の飼育 管理，之殺・解体処理，カッ卜，加工，流通，販売㧍よ び消費にいたるすべての過程において危害分析 (Hazard Analysis: HA: 危害の予測と防止措置の構築) を行い，さらに重要管理点 (Critical Control Point: CCP：危害の制御または排除すべき工程の確認）を明ら かにし, 病原微生物污染, 有害残留物質, 異物混入など を制御する必要がある.

欧米諸国においては，食品の衛生管理方式として $\mathrm{HACCP}$ 方式を導入する国が増加し，米国では水産食 品, 食肉製品類 (USDA) に導入が決定している，また, $\mathrm{EU}$ は, 1995年から水産食品, 食肉製品, 乳製品に導入さ れ，カナダ,ニュージーランドおよびオーストラリアで は, 主に輸出食品の製造・処理工程等に適用されている. わが国のと畜場における衛生管理は，これまでと畜の 疾病等の排除を中心に行われ，十分な微生物污染対策が とられてこなかった，食肉生産を行うと畜場は，之殺・ 解体などの処理工程で枝肉が賴便や腸内容物などから微 生物污染を受けやすく，これらの污染の防止を行うこと が緊急課題である。このため厚生省は，1992 年から HACCP システムの考え方を基本とした「と畜場におけ る牛処理工程の衛生管理」, さらに 1994 年からは「畜 場における豚処理工程の衛生管理」について厚生科学研 究班［岩手大学品川邦汎教授］を組織し検討している.

\footnotetext{
*1 画420 静岡市北安東 4-27-2

*2 画020 盛岡市上田 3-18-8
}

本稿では研究班で行われている調査・研究成績を中心 に，これまで得られた結果の概要について紹介する.

\section{1. 調查対象「と畜場」と処理方法}

牛：対米輸出食肉処理施設（対米処理場） 3 施設（群 馬，宮崎，鹿児島）および九州から北海道の既設之畜場 11 施設で，20頭/日以上を処理している中〜大規模施設 を対象とした。既設と畜場の処理方法は機械で剝皮し, 剝皮後内臟摘出 5 施設, ベッド方式 1 施設, 内臟摘出後 剝皮 1 施設および手剝皮で剝皮後内臓摘出 2 施設, 内臟 摘出後剝皮 2 施設であった.

豚: 北海道, 青森, 岩手, 秋田, 新潟, 静岡および鹿 児島の之畜場 7 施設で，500 1,200頭/日を処理してい る中〜大規模施設を対象とした。，と殺・解体処理方法は 打打む水晸留, 追込み, と殺, 放血, 前処理 1 (四肢の切 断, 切皮等), 懸吊, 内臟摘出, 洗浄, 前処理 2 (胸部 腹部などの一部剝皮), 頭取り, 洗浄, 剝皮機（スキン ナー）による全剝皮, 背割り, 洗浄, 枝肉不可食部の除 去，計量，冷蔵工程にわけられた。調查した 6 施設は, 内藏摘出後に一部剝皮し，その後スキンナーで全剝皮し ており，1施設だけが全剝皮後，内臟摘出を行っていた。 なお，スキンナーの構造は，豩き上げ方式と縱型巻取り 方式が各 1 力所, 横型巻取り方式が 5 力所であった.

2. 各処理場における牛・豚処理工程一覧表の作成お よび目視による重要管理点の確認

調查対象処理場ごとにと殺・解体処理工程図を作成し た. また, 各工程ごとに作業員数, 作業内容, 使用機械・ 器具の一覧表を作成し, 肉眼的に観察して污染要因とし て重要で，污染の制御が可能と考えられる工程の高い順 
にCCP-1〜3 までを付加した.

牛：いずれのと畜場も搬入時および繫留時の生体の粪 便による污染, 処理工程時の胸・腹部の一部剥皮および 全剝皮時の体表污染, 内藏摘出時の腸管破損による污染 が重要管理点 (CCP-1) と判定された。また，背割りおよ び最終処理工程の洗浄が重要管理点 (CCP-2) であると考 えられた。

豚：いずれの処理場においても，生体搬入時または熬 留所で糞便等の付着の少ない豚を処理することが重要で あり，CCP-1 と考えられた，と殺解体工程では，腹壁切 開および内臓摘出時に腸管を誤って傷つけ腸内容物の漏 出により污染されることから，この工程も CCP-1 であ り，また，全剝皮前の一部剥皮の作業および一部剝皮す ることで皮下織が露出した胸部，腹部にと体の皮膚が接 触して污染を起こす工程, さらに, 全㔀皮時のスキン ナーおよび滑り台での污染も CCP-1 と推定された。こ の他, 内臓摘出前の前処理工程-1（四肢の切断とその一 部剝皮), スキンナー後の不可食部の除去, 枝肉洗浄後の 水切り工程も污染要因として高く CCP-2 と判定された.

3. と畜処理最終工程における枝肉污染の調查方法

1) 供試材料

牛：枝肉の検査部位は，一部剝皮工程で污染を受けや すい腹部および胸部，枝肉の洗浄時に污染菌が集積しや すく，また飛水により污染を受けやすい頸部，ならびに 内臓摘出時の腸管等の破損により污染を受けやすい胸腔 部 (胸膜面) の 4 個所を対象とした.

豚：処理工程で最も污染を受けやすい胸部，污染の少 ない背部および使用機械・器具等を対象とした。

牛および豚枝肉，機械・機具等の試料採取方法は，枝 肉等の表面 $100 \mathrm{~cm}^{2}$ をトルクピンセットを用いガーゼ タンポンで, $300 \mathrm{~g}$ 圧以上の強さで拭き取り供試した.

\section{2) 污染菌数測定法}

いずれの検体も各拭き取り材料に滅菌生理食塩水 100 $\mathrm{m} l$ を加えストマッカー処理したものを試料原液とし, 適宜 10 倍段階希釈した。
生菌数は, 標準寒天平板培養法またはスパイラルシス テム法により行った．調整した培地は，30〜 $32^{\circ} \mathrm{C}, 48 \pm$ 3 時間培養した。 また, 大腸菌群数はデソキシコレート 寒天培地を用い $35^{\circ} \mathrm{C}, 20 \pm 2$ 時間培養後, 定型的集落数 を算定した。

4. ウシ処理施設および処理工程の衛生的評価点方式 による污染要因の検討

ウシの処理施設については, 冬期と夏期の 2 回にわた り生菌数および大腸菌群污染を調べ，各部位の污染菌数 と検体数の割合から $0 \sim 10$ 点満点の評価点を付け, 施設 の衛生状態を評価した。

生菌数污染の評価点は, 菌数 10 以下 $/ \mathrm{cm}^{2} に 10$ 点, $10^{1} \sim 10^{2} \mathrm{cfu} / \mathrm{cm}^{2}$ に 8 点, $10^{2} \sim 10^{3} \mathrm{cfu} / \mathrm{cm}^{2}$ に 6 点, $10^{3} \sim 10^{4} \mathrm{cfu} / \mathrm{cm}^{2}$ に 4 点, $10^{4} \sim 10^{5} \mathrm{cfu} / \mathrm{cm}^{2}$ に 2 点, $10^{5} \mathrm{cfu} / \mathrm{cm}^{2}$ 以上は 0 点とした。 このスコアにそれぞれ の菌数を示した検体数をかけ合わせ，その総和を検体数 で割ったものを評価点とした．大腸菌群污染の評価点 は, 大腸菌群が検出されない時 10 点, 検出菌数 $1 \sim 9$ $\mathrm{cfu} / \mathrm{cm}^{2} 4$ 点, $9 \sim 30 \mathrm{cfu} / \mathrm{cm}^{2} 3$ 点, $30 \sim 99 \mathrm{cfu} / \mathrm{cm}^{2} 1$ 点, $10^{2} \mathrm{cfu} / \mathrm{cm}^{2}$ 以上の場合 0 点とし，以下生菌数之同 様な方法によって評価点を求めた。

その結果, 対米処理場 3 施設では, 腹部, 胸部, 頸部 および胸腔部とも高い評価点 (污染が低い) が得られた。 これに対し，既設と畜場 11 個所では，対米処理場に比 べて低い評価点（污染が高い）であった，大腸菌群污染 についてあ同様な傾向が示された（表 1,2）.

と畜場の処理工程ごとに枝肉の微生物污染に係わる污 染要因を挙げ，と畜場別の評価点との関連性について調 查した。

放血時のと体污染は，放血前に吊り上げる方式が低 く, 衛生的処理としては有効であると判定された.この 結果は，対米処理場を除いても同じ評価が得られた。同 様に，と殺から内臟摘出までの水の使用は使用しないこ と，枝肉の洗浄では，ホース洗浄よりピストル式洗浄の 方が，また，床からの飛水による污染がない方が高い評

表 1 各施設の牛枝肉（各部位）の生菌数污染（冬・夏期）からの評価点

\begin{tabular}{|c|c|c|c|c|c|c|c|c|c|c|c|}
\hline \multirow{3}{*}{ 検查対象施設 $(n)$} & \multicolumn{8}{|c|}{ 各部位の評価点 } & \multicolumn{2}{|c|}{ 評価点の比較 } & \multirow{3}{*}{ 総合評価点 } \\
\hline & \multicolumn{2}{|c|}{ 腹 部 } & \multicolumn{2}{|c|}{ 胸 部 } & \multicolumn{2}{|c|}{ 頸 部 } & \multicolumn{2}{|c|}{ 胸 腔 } & \multirow[b]{2}{*}{ 冬期 } & \multirow[b]{2}{*}{ 夏期 } & \\
\hline & 冬期 & 夏期 & 冬期 & 夏期 & 冬期 & 夏期 & 冬期 & 夏期 & & & \\
\hline 対米輸出施設 (3) & 7.5 & 7.5 & 7.5 & 7.4 & 7.8 & 7.6 & 9.0 & 9.5 & 8.0 & 8.0 & 7.9 \\
\hline 既設処理施設 (11) & 4.5 & 4.6 & 4.9 & 4.3 & 5.4 & 4.9 & 6.5 & 5.9 & 5.4 & 4.9 & 5.2 \\
\hline
\end{tabular}

表 2 各施設の牛枝肉（各部位）の大腸菌群污染（冬・夏期）からの評価点

\begin{tabular}{|c|c|c|c|c|c|c|c|c|c|c|c|}
\hline \multirow{3}{*}{ 検査対象施設 $(n)$} & \multicolumn{8}{|c|}{ 各部位の評価点 } & \multicolumn{2}{|c|}{ 評価点の比較 } & \multirow{3}{*}{ 総合評価点 } \\
\hline & \multicolumn{2}{|c|}{ 腹 部 } & \multicolumn{2}{|c|}{ 胸 部 } & \multicolumn{2}{|c|}{ 頸 部 } & \multicolumn{2}{|c|}{ 胸 腔 } & \multirow[b]{2}{*}{ 冬期 } & \multirow[b]{2}{*}{ 夏期 } & \\
\hline & 冬期 & 夏期 & 冬期 & 夏期 & 冬期 & 夏期 & 冬期 & 夏期 & & & \\
\hline 対米輸出施設 (3) & 9.2 & 9.0 & 9.0 & 9.2 & 9.4 & 9.2 & 9.9 & 9.8 & 9.4 & 9.2 & 9.3 \\
\hline 既設処理施設 (11) & 7.5 & 6.2 & 7.5 & 6.2 & 7.7 & 6.3 & 8.9 & 7.9 & 8.0 & 6.7 & 7.3 \\
\hline
\end{tabular}


表 3 牛枝肉の微生物污染と各と畜場の評価点（生菌数） 牛枝肉の微生物污染にかかわる調查 1

\begin{tabular}{|c|c|c|c|c|c|c|c|c|c|c|c|c|c|c|c|c|}
\hline \multirow{3}{*}{ 検査対象施設 $(n)$} & \multirow{3}{*}{$\begin{array}{l}\text { 総合 } \\
\text { 評価点 }\end{array}$} & \multicolumn{3}{|c|}{ 放血の方法 } & \multicolumn{2}{|c|}{$\begin{array}{c}\text { 之殺〜内臓 } \\
\text { 検査までの } \\
\text { 水の使用 }\end{array}$} & \multicolumn{6}{|c|}{ 枝肉の洗浄について } & \multicolumn{2}{|c|}{$\begin{array}{c}\text { 枝肉之床・ } \\
\text { 壁の接触 }\end{array}$} & \multicolumn{2}{|c|}{ 軍手の使用 } \\
\hline & & \multicolumn{3}{|c|}{ 吊下げ } & \multirow[b]{2}{*}{ 有 } & \multirow[b]{2}{*}{ 無 } & \multicolumn{2}{|c|}{ 洗浄方法 } & \multicolumn{2}{|c|}{ 十分に洗浄 } & \multicolumn{2}{|c|}{ 床からの飛水 } & \multirow[b]{2}{*}{ 有 } & \multirow[b]{2}{*}{ 無 } & \multirow[b]{2}{*}{ 有 } & \multirow[b]{2}{*}{ 無 } \\
\hline & & 放血前 & 们放血後 & 放血中 & & & ホース & ピストル & 有 & 無 & 有 & 無 & & & & \\
\hline 対米輸出施設 (3) & 7.9 & 7.9 & & & & 7.9 & & 7.9 & 7.9 & & & 7.9 & & 7.9 & & 7.9 \\
\hline 既設処理施設 (11) & 5.2 & $6.8(1)$ & $5.1(7)$ & $4.8(3)$ & $5.0(9)$ & $6.0(2)$ & $4.6(4)$ & $5.5(7)$ & $5.6(6)$ & $4.7(5)$ & $5.0(4)$ & $5.3(7)$ & $5.1(10)$ & $5.4(1)$ & $5.0(10)$ & $6.8(1)$ \\
\hline
\end{tabular}

表 4 牛枝肉の微生物污染と各と畜場の評価点（生菌数） 牛枝肉の微生物污染にかかわる調查 2

\begin{tabular}{|c|c|c|c|c|c|c|c|c|c|c|c|c|c|c|c|c|}
\hline \multirow{3}{*}{ 検查対象施設 $(n)$} & \multirow{3}{*}{$\begin{array}{l} \\
\text { 総合 } \\
\text { 評価点 }\end{array}$} & \multirow{2}{*}{\multicolumn{2}{|c|}{\begin{tabular}{|c} 
食道結紮して \\
いない場合 \\
漏出污染頻度
\end{tabular}}} & \multicolumn{2}{|c|}{$\begin{array}{l}\text { 乳房除去時 } \\
\text { のと体污染 }\end{array}$} & \multicolumn{4}{|c|}{ 剝皮前処理における污染 } & \multirow{2}{*}{\multicolumn{2}{|c|}{$\begin{array}{c}\text { 剝皮による } \\
\text { と体污染 }\end{array}$}} & \multicolumn{5}{|c|}{ 内臓摘出時による污染 } \\
\hline & & & & \multirow[b]{2}{*}{ 有 } & \multirow[b]{2}{*}{ 無 } & \multicolumn{2}{|c|}{ 手による污染 } & \multicolumn{2}{|c|}{ 残毛の付着 } & & & \multicolumn{2}{|c|}{ 腹部切開時 } & \multicolumn{3}{|c|}{ 内臟摘出時 } \\
\hline & & $\begin{array}{l}<1 / \\
10 \text { 頭 }\end{array}$ & $\begin{array}{l}2 \sim 5 / \\
10 \text { 頭 }\end{array}$ & & & 有 & 無 & 有 & 無 & 有 & 無 & 無 & $\begin{array}{l}<1 / \\
10 \text { 頭 }\end{array}$ & 無 & $\begin{array}{l}<1 / \\
10 \text { 頭 }\end{array}$ & $\begin{array}{l}2 \sim 5 / \\
10 \text { 頭 }\end{array}$ \\
\hline 対米輸出施設 (3) & 7.9 & - & & & 7.9 & & 7.9 & $9.1(1)$ & $7.3(2)$ & $7.3(2)$ & 9.1(1) & $8.3(2)$ & $7.2(1)$ & $8.3(2)$ & $7.2(1)$ & \\
\hline 既設処理施設 (11) & 5.2 & $5.5(7)$ & $4.6(4)$ & $5.1(7)$ & $5.3(4)$ & $4.6(10)$ & $6.8(1)$ & $5.0(9)$ & $5.9(2)$ & $5.1(8)$ & $5.4(3)$ & $5.6(2)$ & $5.1(9)$ & $5.7(3)$ & $5.0(6)$ & $4.8(2)$ \\
\hline
\end{tabular}

( ): 施設数

価点が得られた。 さらに，枝肉，床および壁の接触がな いこと，従業員は軍手をしないことが污染を少なくする と判定された，一方，腸内容物の漏出による污染頻度か 少ない施設，乳房除去時の体表污染がない施設，残毛污 染がない施設の評価点が高かった（表 3,4）.

\section{5. 豚処理施設および処理工程の細菌検査に基づく污}

\section{染要因の検討}

ブタ枝肉の污染要因の排除方法を検討するため，と体 体表の洗浄，消毒・殺菌後の細菌数の消長を調へ，有効 な除菌方法について検討した，調査は，(1)各施設で通常 実施していると殺・放血，シャワーリング洗浄後，解体 処理，(2)と殺・放血，シャワーリング後， $50^{\circ} \mathrm{C}$ の 100 $\mathrm{ppm}$ 次亜塩素酸ナトリウム溶液 $20 l$ で消毒殺菌し, 3 分間放置後解体処理する（清潔処理-1），(3)前記(2)の法 で体表を消毒・殺菌処理した後，さらに，之体の切皮部 分を次亜塩素酸ナトリウム溶液 $20 l$ で消毒・殺菌した 後解体処理する（清潔処理-2）の方法について, 各処理 工程の之体（枝肉）の細菌污染状況を調べた。なお，清 潔処理では，と体に接触する機械・器具も同様な薬剤に よって消毒・殺菌した。

\section{1）スキンナー，滑り台の剝皮工程における衛生的処 理と通常処理}

\section{（1）通常処理における経時的な細菌污染}

通常処理における横型スキンナーおよび滑り台の処理 開始前の生菌数は高い傾向を示し，処理開始後 30 分お よび 60 分後もほとんど変わらなかった．大腸菌群数に おいても同様な傾向を示した。したがって作業終了時お よび開始前の使用機械・器具の洗浄消毒が重要であるこ とが示された。
（2）スキンナーおよび滑り台の消毒前・後の細菌污 染

と体を一頭剝皮した後，横型スキンナーおよび滑り台 を次亜塩素酸ナトリウム $50 \mathrm{ppm}\left(50^{\circ} \mathrm{C}\right)$ 溶液で消毒後を 行うと, 生菌数 $<10 \mathrm{cfu} / \mathrm{cm}^{2}$ 以下, 大腸菌群数は検出さ れなくなった。 しかし消毒後，次のと体を剝皮した場合 は，スキンナー，滑り台とも再污染されることが明らか になった。

\section{(3) 衛生的処理と通常処理時のと体胸部の污染}

通常処理および衛生的処理した場合，いずれも胸部の 染菌数に差はみられなかった。 と体胸部の污染は，全剥 皮前に一部㔀皮した部位がと体の接触により高度に污染 されるためと考えられた。 また，最終工程での枝肉胸部 の污染数は, 衛生的処理および通常処理とも $10 \sim 10^{4}$ $\mathrm{cfu} / \mathrm{cm}^{2}$ の範囲で差はみられなかった，大腸菌群数にお いても同様な傾向を示した.さらに，胸部の污染菌数は， 一部剝皮より全剝皮後で高く，以後の工程，すなわち背 割り・洗浄, 水切り後む減少しなかった。

一部剝皮前のと体胸部の污染菌数は, $10^{2} \sim 10^{5} \mathrm{cfu} /$ $\mathrm{cm}^{2}$ を示した。一部剥皮前のと体表面の污染が少ないほ よ゙，最終と体の污染菌数は少ない傾向がみられた。

(4) 生体時およびシャワーリング後の污染菌数

と畜場に搬入された豚のシャワーリング前の体表の生 菌数は, $10^{5} \sim>10^{6} \mathrm{cfu} / \mathrm{cm}^{2}, \quad$ シャワーリング後は $10^{4}$ $\mathrm{cfu} / \mathrm{cm}^{2}$ で内臓摘出後とほとんど同じであった。 また， 生体体表の污染菌数が少ないほよ゙，最終枝肉の胸部の污 染菌数は少ない傾向がみられた。したがって，と体体表 の污染菌数を減少させることが極めて重要と考えられ た. 
2) 横型および縦型スキンナーによると体污染の比較

豩皮後の胸部の污染菌数は, 横型および綎型スキン ナーとも変わらなかった. しかし, 豩き上げスキンナー 方式は, 横型に比べ 10 $10^{2} \mathrm{cfu} / \mathrm{cm}^{2}$ 少ない污染を示し た. と体をシャワーリング後, 次亜塩素酸ナトリウムで 消毒殺菌し,さらに切皮個所を消毒殺菌したと体を解体 処理した場合（清潔処理-2）, 横型および縦型ともに污 染菌数は減少した。しかし, 両者ともに一部剝皮工程後 加ら, 全剝皮後において污染菌数は増加した。 大腸菌群 数においても同様な傾向を示した。

剝皮後の背部の污染菌数は, 横型および縦型スキン ナーともに清潔処理-2を行うことにより減少したが, 両機種間に差はみられなかった。これらのスキンナーに 比べて, 剝き上げ方式の污染菌数は少なく, 生菌数は, $<10 \mathrm{cfu} / \mathrm{cm}^{2}$ であった. 大腸菌群数も同様な傾向を示 した.

これらの成績から縦型スキンナー, 特に剝き上げ方式 は，乙体体表が機械に接触せず，枝肉背部の污染が少な い. しかし, 胸部の污染スキンナーで㔀皮する前に発生 するので, 全剝皮工程前の污染防止が重要であることが 分かった。

\section{3）と体を洗浄消毒した場合の体表污染の制御}

と体の体表 (胸部) を清潔処理-1〜2で処理した場合 には, 放血洗浄後の污染菌数が $10 \sim 10^{2} \mathrm{cfu} / \mathrm{cm}^{2}$ に減少 した. しかし, 清潔処理-1 では, 通常処理と同程度の生 菌数および大腸菌群数を示した.これに対し清潔処理-2 では, 污染菌数も少なく生菌数が $10 \sim 10^{2} \mathrm{cfu} / \mathrm{cm}^{2}$ を示 し, 大腸菌群数もほとんど検出されなかった。しかし, 全㔀皮後には污染生菌数は $10^{1} \sim 10^{4} \mathrm{cfu} / \mathrm{cm}^{2}$ に増加 し, 最終と体においても, その污染菌数は変わらなかっ た（表 5).

一方, と殺後の背部の污染菌数は, 胸部の污染菌数之 同程度であり, 生菌数は $10^{2} \sim 10^{6} \mathrm{cfu} / \mathrm{cm}^{2}$, 大腸菌群数 は $<10^{3} \mathrm{cfu} / \mathrm{cm}^{2}$ であった. 清潔処理-1〜2では放血・ 洗浄後の生菌数が $10^{2} \sim 10^{3} \mathrm{cfu} / \mathrm{cm}^{2}$ に減少し, 内藏摘 出後も通常処理に比べて污染菌数は低かった。しかし, 全剝皮後では, 清潔処理-1 と通常処理を行ったものは 同程度の污染菌数であった. これに対し清潔処理-2で は, 明らかに低い污染菌数であり,また, 最終と体も全 剝皮後の菌数之変わらなかった（表 6 ).

4) 処理工程中の亡体の污染要因

(1) と体の接触による污染

ほとんどの施設でスキンナーで㔀皮する前にと体が滞

表 5 全剝皮スキンナー（横型と縦型）による豚と体の細菌污染 通常処理 一胸部一

\begin{tabular}{|c|c|c|c|c|c|c|c|c|c|c|c|c|c|c|c|}
\hline \multirow{2}{*}{ 工程 } & \multirow{2}{*}{$\begin{array}{l}\text { スキン } \\
\text { ナー型 }\end{array}$} & \multirow{2}{*}{ 検体数 } & \multicolumn{7}{|c|}{ 生菌数 $\left(\mathrm{cfu} / \mathrm{cm}^{2}\right)$} & \multicolumn{6}{|c|}{ 大腸菌群 $\left(\mathrm{cfu} / \mathrm{cm}^{2}\right)$} \\
\hline & & & $<10$ & $<10^{2}$ & $<10^{3}$ & $<10^{4}$ & $<10^{5}$ & $<10^{6}$ & $10^{6} \leqq$ & 検出せず & $<10$ & $<30$ & $<10^{2}$ & $<10^{3}$ & $10^{3} \leqq$ \\
\hline \multicolumn{16}{|c|}{ 横型 ～～～～～} \\
\hline \multirow{2}{*}{\multicolumn{2}{|c|}{$\begin{array}{l}\text { 一部剝皮後 } \\
\text { 全剝皮後 }\end{array}$}} & 84 & 5 & 18 & 34 & 21 & 5 & 1 & - & 47 & 22 & 10 & 2 & 2 & 1 \\
\hline & & 84 & 1 & 5 & 49 & 23 & 5 & 1 & - & 41 & 30 & 5 & 3 & 4 & 1 \\
\hline \multicolumn{16}{|c|}{ 縦型 } \\
\hline & 㓭㩆皮後 & 9 & 3 & 5 & 1 & - & - & - & - & 8 & 1 & - & - & - & - \\
\hline \multicolumn{16}{|c|}{ 卷取り方式 } \\
\hline & 部㩆皮後 & 18 & - & 1 & 3 & 12 & 2 & - & - & 2 & 7 & 5 & 4 & - & - \\
\hline & 嵝皮後 & 18 & - & - & - & 10 & 8 & - & - & - & 3 & 11 & 3 & 1 & - \\
\hline
\end{tabular}

清潔処理-2 一胸部一

\begin{tabular}{|c|c|c|c|c|c|c|c|c|c|c|c|c|c|c|c|}
\hline \multirow{2}{*}{ 工程 } & \multirow{2}{*}{$\begin{array}{l}\text { スキン } \\
\text { ナー型 }\end{array}$} & \multirow{2}{*}{ 検体数 } & \multicolumn{7}{|c|}{ 生菌数 $\left(\mathrm{cfu} / \mathrm{cm}^{2}\right)$} & \multicolumn{6}{|c|}{ 大腸菌群 $\left(\mathrm{cfu} / \mathrm{cm}^{2}\right)$} \\
\hline & & & $<10$ & $<10^{2}$ & $<10^{3}$ & $<10^{4}$ & $<10^{5}$ & $<10^{6}$ & $10^{6} \leqq$ & 検出せず & $<10$ & $<30$ & $<10^{2}$ & $<10^{3}$ & $10^{3} \leqq$ \\
\hline \multicolumn{16}{|l|}{ 横型 } \\
\hline \multirow{2}{*}{\multicolumn{2}{|c|}{$\begin{array}{l}\text { 一部剝皮後 } \\
\text { 全剝皮後 }\end{array}$}} & 15 & 5 & 9 & 1 & - & - & - & - & 12 & 3 & - & - & - & - \\
\hline & & 15 & - & 4 & 8 & 3 & - & 一 & - & 11 & 4 & - & - & - & - \\
\hline \multicolumn{16}{|c|}{ 縦型 } \\
\hline & 队剝皮後 & 9 & 5 & 2 & 2 & - & - & - & - & 8 & 1 & - & - & - & - \\
\hline \multicolumn{16}{|c|}{ 卷取り方式 } \\
\hline & 淥皮後 & 3 & 1 & 2 & - & - & - & - & - & 3 & - & - & - & - & - \\
\hline & 利皮後 & 3 & 2 & 1 & - & - & - & - & - & 3 & - & - & - & - & - \\
\hline
\end{tabular}

縦型 巻取り方式：横型スキンナーを縦型にしたもの

清潔処理-2: 之殺・放血, シャワーリン洗浄後, 再度ブラシング洗浄, $100 \mathrm{ppm}$ 次塩素酸ナトリウム $\left(50^{\circ} \mathrm{C}\right)$ でと体を消毒殺菌 し, さらに解体処理時に切皮部分を再度消毒殺菌して解体処理を行う 
表 6 通常, 清潔-1 および清潔-2 処理による工程別の細菌数污染 一背部一

\begin{tabular}{|c|c|c|c|c|c|c|c|c|c|c|c|c|c|c|c|}
\hline \multirow{2}{*}{ 工 程 } & \multirow{2}{*}{$\begin{array}{l}\text { 処理 } \\
\text { 方法 }\end{array}$} & \multirow{2}{*}{ 検体数 } & \multicolumn{7}{|c|}{ 生菌数 $\left(\mathrm{cfu} / \mathrm{cm}^{2}\right)$} & \multicolumn{6}{|c|}{ 大腸菌群 $\left(\mathrm{cfu} / \mathrm{cm}^{2}\right)$} \\
\hline & & & $<10$ & $<10^{2}$ & $<10^{3}$ & $<10^{4}$ & $<10^{5}$ & $<10^{6}$ & $10^{6} \leqq$ & 検出せず & $<10$ & $<30$ & $<10^{2}$ & $<10^{3}$ & $10^{3} \leqq$ \\
\hline \multirow{3}{*}{ と殺後 } & 通 常 & 60 & - & - & 4 & 13 & 25 & 18 & - & 7 & 23 & 12 & 4 & 14 & - \\
\hline & 清潔 1 & 60 & - & - & 4 & 28 & 22 & 5 & - & 23 & 22 & 6 & 2 & 7 & - \\
\hline & 清潔 2 & 18 & - & - & 6 & 11 & 1 & - & - & 6 & 9 & 2 & 1 & - & - \\
\hline \multirow{3}{*}{$\begin{array}{l}\text { 放血・ } \\
\text { 洗浄後 }\end{array}$} & 通 常 & 50 & - & - & 4 & 23 & 22 & 1 & - & 13 & 31 & 5 & 1 & - & - \\
\hline & 清潔 1 & 60 & 20 & 16 & 11 & 9 & 4 & - & - & 54 & 4 & - & 1 & 1 & - \\
\hline & 清潔 2 & 18 & 1 & 3 & 6 & 8 & - & - & - & 15 & 3 & - & - & - & - \\
\hline \multirow{3}{*}{$\begin{array}{l}\text { 内 臟 } \\
\text { 摘出後 }\end{array}$} & 通 常 & 60 & - & 1 & 11 & 26 & 16 & 6 & - & 15 & 31 & 8 & 4 & 2 & - \\
\hline & 清潔 1 & 60 & 7 & 11 & 20 & 14 & 8 & - & - & 37 & 16 & 3 & 1 & 3 & - \\
\hline & 清潔 2 & 18 & 3 & 4 & 9 & 2 & - & - & - & 14 & 4 & - & - & - & - \\
\hline \multirow{3}{*}{$\begin{array}{ll}\text { 全 㔀 } \\
\text { 皮 後 }\end{array}$} & 通 常 & 60 & 8 & 12 & 31 & 7 & 2 & - & - & 39 & 15 & 5 & 1 & - & - \\
\hline & 清潔 1 & 60 & 13 & 12 & 22 & 12 & 1 & - & - & 37 & 14 & 6 & 2 & 1 & - \\
\hline & 清潔 2 & 18 & 9 & 9 & - & - & - & - & - & 18 & - & - & - & - & - \\
\hline \multirow{3}{*}{$\begin{array}{cc}\text { 最 } & \text { 終 } \\
\text { と } & \text { 体 }\end{array}$} & 通 常 & 60 & 4 & 26 & 18 & 12 & - & - & - & 40 & 12 & 6 & 2 & - & - \\
\hline & 清潔 1 & 60 & 10 & 19 & 26 & 5 & - & - & - & 34 & 14 & 9 & 1 & 2 & - \\
\hline & 清潔 2 & 18 & 5 & 11 & 2 & - & - & - & - & 17 & 1 & - & - & - & - \\
\hline
\end{tabular}

清潔処理-1: と殺・放血, シャワーリング洗浄後, $100 \mathrm{ppm}$ 次亜塩素酸ナトリウム $\left(50^{\circ} \mathrm{C}\right)$ でと体を消毒・殺菌して解体処理した 場合

清潔処理-2: と殺・放血，シャワーリング洗浄後，再度ブラシング洗浄， $100 \mathrm{ppm}$ 次亜塩素酸ナトリウム $\left(50^{\circ} \mathrm{C}\right)$ でと体を消毒・ 殺菌，さらに解体時に切皮する部分を再度消毒・殺菌して解体処理した場合

留し，一部剝皮した部分と皮虑が接触し，また滞留時の 冷却に用いているシャワーリングにより，污染が拡散し ていた，之体が接触した場合は，接触がない場合に比べ て生菌数拉よび大腸菌群数ともに高い污染を示した.

\section{(2) 腸内容物による污染菌数とシワャーリング効果}

内㵴摘出時の腸管破損により内容物がと体を污染した 場合の菌数は, $<10^{3} \sim 10^{7} \mathrm{cfu} / \mathrm{cm}^{2}$ を示し, シャワーリ ングによって $10^{1} \mathrm{cfu} / \mathrm{cm}^{2}$ 減少が見られた。 大腸菌群数 もと体によって大きな差が見られたが，これは腸管の破 損部位による内容物の違いや污染した量によることが考 えられる。

\section{5）罊留所におけるシャワーリング前後の生体体表の 污染菌数}

生体の体表の生菌数は，目視によって污れが少ない豚 で $<10^{3} \sim 10^{7} \mathrm{cfu} / \mathrm{cm}^{2}$, 污れが目立つ豚でも $<10^{4} \sim 10^{7}$ $\mathrm{cfu} / \mathrm{cm}^{2}$ であった．この污染菌数はシャワーリングに よってもほとんど減少しなかった．繫留所の床の污染生 菌数は, $<10^{6} \sim 10^{7} \mathrm{cfu} / \mathrm{cm}^{2}$ で繫留時の体表污染源と なることが考えられる。

\section{6) 最終枝肉の部位別による污染菌数}

一部剝皮する左胸部は, と体の接触等により污染され ることが判明したが，最終と体になると左右の胸部とも に同程度の污染菌数であった，その他，頸部の污染が最 あ高く, 次いで背部および胸部の順であった。

豚処理工程における污染要因とその制御に関する検討 からわが国の施設で多く利用されている横型スキンナー は，一頭処理ごとに消毒しても污染を減少させることは できず，CCP としての対象にならなかった。しかし，と
体体表を十分洗浄後, 次亜塩素酸ナトリウムで消毒殺菌 し, 体表の污染菌数が少ない場合には, 最終と体体表の 污染菌数を減少させることが可能であった。これに対し 縦型スキンナー（剝き上げ方式）は，子体背部の污染防 止に有効であった。

\section{まと め}

わが国のと畜場における牛および豚処理工程での枝肉 の微生物污染と, その制御方法について HACCP システ ムに基づき検討した．調査したと畜場は，老朽化し構造 や設備の改善が必要な個所がみられた，また，基本的に は, 処理工程での生体からの糞便污染, 腸内容物の拡散, 作業者の手指, 機械機具などからの污染要因が明らかに なった，特に一度污染された枝肉は，洗浄，消毒によっ て完全に除菌することができず，したがって，污染させ ないための設備構造ならびに取扱い方法の改善を考慮し つつ， HACCP に基づく衛生管理が必要であると考えら れる，今後は，今日までの成績で不十分な点を補いなが ら管理基準，モニタリング，改善措置，検証方法，記録 保存の設定について検討し, 衛生的な処理方法の確立に 向けて作業が進められる予定である.

以上の成績は, 厚生科学研究費 (乳肉衛生課) によっ て実施されたものであり, また, 北海道 (八雲, 早来), 青森 (十和田), 岩手 (柴波), 秋田 (中央), 群馬 (中央), 埼玉, 横浜市, 静岡 (東部, 西部), 静岡市, 新潟 (長岡), 三重 (松阪), 奈良, 宮崎 (高崎), 鹿児島県 (志布志, 南末吉, 知覧) の各食肉衛生検查所, 岩手, 埼玉, 静岡, 新潟, の各県衛生研究所, 国立衛生試験所, 国立公衆衛 
20 日食微誌 Vol. 14 No. 11997

生院, 麻布大学保健環境学部, 日本八ム, 伊藤ハム, プ リマハムの研究所の協力によって行われたあのであり, 記して感謝いたします。

\section{参考文献}

1）豊福 政：カナダ農務省による食品の安全強化プログラ ムについて (1〜3). 食品衛生研究, 44(4, 12), 47-65, 2970 (1994).

2) 岡山秀光：と畜場の施設および施設に関するガイドライ ンに付いて, 食品衛生研究, 44(10), 9-46 (1994).
3) 品川邦汎：之畜場の之殺解体処理工程における微生物污 染の実態一と畜場における HACCP を基本とする衛生管 理指針の作成に向けて．獣医畜産新報，47(7), 587-591 (1994).

4）川端俊治, 春田三佐夫：HACCP一これからの食品工場の 自主衛生管理, 中央法規, 東京 (1992).

5）仁科徳啓，小沼博隆：食品への予測微生物学の適用. 矢 野信禮, 小林登志夫, 藤川 浩, p. 126-140, (株)サイ エンスフォーラム, 東京(1997) 


\author{
魚介 類 \\ 豊福肇 \\ （厚生省生活衛生局乳肉衛生課）
}

\title{
Symposium B The Sanitary Control of Food Materials Based on HACCP System
}

\section{A Hygiene Quality Control of Fish and Fishery Product}

\author{
Hajime Toyofuku \\ (Veterinary Sanitation Division Environmental Health Bureau Ministry of Health \& Welfare)
}

Key words: HACCP, Seafood

\section{1. 水産食品に HACCP が適用される理由}

水産食品は，その衛生管理の手法として HACCP シス テムの導入が最あ広範囲に進んでいる食品の一つであ る. その理由としてはつぎのようなことが考えられる。

（1）食用に供する魚介類の種類が多い，その中には地 域的には食経験が乏しいものがあること。

（2）採捕される海域ごとに，季節ごとに毒化すること がありうること.

(3) 取扱いにより, 腐敗変敗しやすい食品であるこ 之.

（4）微生物のみならず, 多くの危害の原因物質が考え られること。

（5）以上のことから採捕から製造加工，保管まで一貫 して管理しないと食品の衛生を確保するのが困難な こと.

\section{2. 水産食品における HACCP の実施状況}

世界中の水産食品の衛生管理に HACCP システムが 適用される理由は, 2 大マーケットである EC 域内とア メリカに輸出するためには, 輸出国の加工施設が HACCP システムの実施を含むこれらの地域の規制を満 たさなければならないことが考えられる。 そこでこれら の地域における水産食品の規制について紹介する.

(1) 欧州委員会

欧州では, EC 域内で流通する水産食品について, $\mathrm{EC}$ 加盟国または $\mathrm{EC}$ 域外の輸出国政府が $\mathrm{EC}$ 指令 に基づき，衛生規制を適切に行っていることについ て, 証明書の添付により, それを保証することを求 めている. この際, 漁獲から原材料の保管, 製造, 加工，製品の保管までの施設における食品衛生を確 画100-45 東京都千代田区霞が関 1-2-2
保するため，一貫した衛生管理を行うことを求めて いる.

具体的には, 一般水産食品のための指令 (EC Council Directive 91/493/EEC)，二枚貝に関する 指令 (EC Council Directive 91/492/EEC) および 漁船に関する指令 (EC Council Directive 92/42/ EEC) があとになり, 個別具体的な通知として, 甲 殼類および貝類の微生物規格に関する指令 (EC Council Decision 93/51/EEC), 寄生虫の検查に関 する指令 (EC Council Decision 93/140/EEC), 水 銀の検查に関する指令 (EC Council Decision 93/ 351/EEC), HACCP に関する指令 (EC Council Decision 94/356/EEC), TVBN の検査に関する指 令 (EC Council Decision 95/149/EEC), 飲用水 （使用水を含む）の規格に関する指令 (EC Council Decision 95/149/EEC) の各要件を満たす必要があ る.

このうち, 一般水産食品のための指令 (EC Council Directive 91/493/EEC) において, 施設の構造 設備の基準，施設設備の衛生管理の基準，従事者の 衛生管理, 生鮮品に関する基準, 冷凍品に関する個 別基準，解凍品に関する個別基準，加工品に関する 個別基準（この中で加熱時間および温度, 塩分含有 率, $\mathrm{pH}$ および水分含有量を監視管理することが求 められているとともに, 缶詰, 䨘煙品, 塩蔵品, 甲 殼類および軟体動物の加工品ならびに機械を使用し て回収する魚肉に関する個別基準が設けられてい る.），寄生虫コントロールのための基準，水銀およ び全揮発性窒素に関する自主検査に関する基準およ び包装, 表示, 保管に関する要件が規定されている. これに加え， HACCP に関する指令（EC Council 
Decision 94/356/EEC) 基づき, Codex のガイドラ インに沿った HACCP 方式を用いた自主衛生管理 を行うことが求められている.

二枚貝については, 上記一般水産食品の要件に加. え, 二枚貝に関する指令 (EC Council Directive 91/492/EEC) に基づき, (1)水産海域における貝毒 のモニタリング体制の整備とその実施，(2)モニタリ ング結果に基づき生産海域の指定または開鎖ならび に生産海域の監視, (3)貝毒検查のための検查機関の 精度管理および各検查機関の外部精度管理を実施 し，評価をするリファレンスラボの設置，(4)麻痺性 貝毒の検查のための標準品としてサキシトキシンを 使用し，アッセイに用いるマウスの感受性の補正等 が求められている.

(2) 米国

米国で製造・加工および米国内に輸入される水産 食品については, 従来から 21CFR Part 110 の Current Good Manufacturing Practice および個 別に設定されていた基準値, アクションレベル等を 満たすことが求められていたが，1995 年 12 月 17 日に公示され 97 年 12 月 18 日から施行される 21 CFR Part $123\lceil$ Fish and Fishery Product」(いわ ゆる Seafood Hazard Analysis Critical Control Point (HACCP) regulation）に基づき, 水産食品の 加工者は施設ごと, 食品ごとに危害分析を行い, 食 品衛生上の危害が認められる場合には, HACCP 7 原則に基づき, $\mathrm{CCP}$ の特定, 管理基準の設定, モ二 タリング方法の設定, 改善措置の設定, 検証方法の 設定および記録の維持管理システムを含む HACCP プランを施設毎に作成し，実施することが求められ ている.

Current Good Manufacturing Practice のなか においては, 従事者の疾病管理, 清潔保持, 教育訓 練等, 施設およびその周囲の構造設備の要件, 施設 設備の保守点検, 衛生管理, そ族昆虫の防除, 洗剤 殺菌剤の使用, 給水, 排水, 下水, 便所および手洗 い設備等衛生設備の管理, 設備および機械器具の要 件ならびに原材料の取扱い，製造作業，保管および 出荷に係る食品等の衛生的な取扱いの要件が規定さ れている.

米国の Seafood HACCP 規則の内容は以下のと 扣り。

(1) 危害分析

すべての加工者は当該加工者が加工している魚 介類およびその加工品の種類によって起こりうる 食品衛生上の危害を特定し, かつそれらの危害に 対し, 加工者が実施することができる防止措置を 明らかにするために危害分析を行うこと，そのよ うな食品衛生上の危害は, 加工施設の内外で食品 に持ち込まれ, また漁獲の前, 途中, および後に
起こりうるあのを含む，起こりうる食品衛生上の 危害とは, 加工者が経験, 疾病のデー夕, 科学的 な報告，その他の情報から，特定のタイプの魚介 類およびその加工品の加工において，適切な管理 が行われなかった場合には，合理的な可能性で危 害が起こりうると結論付け, 管理方法が設定され ていたあのである.

(2) The HACCP plan すべての加工者は前項(1)により規定された危害 分析により, 起こりうる食品衛生上の危害が一つ 以上明らかになったときは, 文書による HACCP プランを作成し, 実施すること. HACCP プラン は，次の事項により特異的であること.

ア加工者が魚介類およびその加工品を加工する 場所每

1. 加工する魚介類およびその加工品の種類毎 当該プランは, 次項(3)の規定により特定し, 管 理することが求められている危害, 重要管理点, 管理基準および手順が同一の場合, 魚介類および その加工品の種類, または製造加工方法の種類に より，まとめることができる.

(3) HACCP プランの内容

HACCP プランには, 少なくとも次の事項が含 まれていること.

ア (1)の規定に従って危害分析を行った結果, 合 理的に起こりうることが確認されたため, 各々 の魚介類およびその加工品毎にコントロールし なけ机ばならない食品衛生上の危害を死挙する こと. 危害としては, 次のような範囲のあのに ついて, 合理的に起こりうるかどうかについて 考察すべきである.

（ア） 自然毒;

（イ） 微生物;

（ウ） 化学物質;

(I) 農薬;

（才） 動物用医薬品；

（カ） Scombroid toxin-forming species にお ける分解または他のすべての種類の魚介類 およびその加工品における食品衛生上の危 害に関連する分解アミン

（キ） 寄生虫（寄生虫が寄生している魚介類お よびその加工品に対し, 当該寄生虫を死滅 させるのに十分な加工工程を経ないで, 消 費者が喫食することを加工者が知っている 場合または知る理由がある場合，あるいは 加工者がそのように消費されるように提 供, 表示または意図している販売して場合 に限る.）

（ク）認められていない直接または間接食品添 加物あるいは着色料の使用; 
（ケ）物理的な危害

イ 特定された各々の食品衛生上の危害に対する 重要管理点が列挙されていること。なお，これ には次の二つのものが含まれていること.

（ア）加工施設の環境において持ち込まれうる 食品衛生上の危害の発生をコントロールす るために設定された重要管理点.

（イ）漁獲の前，途中および後に起こる食品衛 生上の危害を含む，加工施設の環境外にお いて持ち込まれうる食品衛生上の危害の発 生をコントロールするために設定された重 要管理点.

ウ 各々の重要管理点には, 管理基準 (Critical Limits) が設定されていること.

エ 管理基準に適合していることを確認するた め，モニタリングに用いられる手順および頻度 が設定されていること.

オ 重要管理点において, 管理基準からの逸脱に 対応して採られる改善措置が設定されているこ と.

力 検証の方法および頻度が設定されているこ と.

キ 重要管理点のモニタリング結果の記録を維持 管理するシステムがもうけられていること.こ のモニタリングの記録には，モニタリングに よって得られた正確な值または観察結果が含ま れていること.

(4) 改善措置

ア 管理基準からの逸脱があった場合，加工者 は, 次の措置を採ること.

（ア）特定の逸脱に対し適切な改善措置プラン に従うこと。

または

（イ）この項のウに規定された手順に従うこ 之.

イ 加工者は, 文書による改善措置プランを作成 することになるが，これは(3)才の規定により， HACCP プランの一部となり，管理基準から逸 脱した時に採るために予め改善措置を設定する ことによる. 特定の逸脱に対し適切な改善措置 プランとは，次のことを保証するため，採られ る手段を記述し，それらの手段の責任を負う者 をを指名したものである。

（ア）逸脱の結果，健康に害をむたらすあのま たは品質の粗悪なむのを流通経路に入れな い.

（イ）逸脱の原因を改善する.

ウ 管理基準からの逸脱が発生し，加工者が当該 逸脱に対し適切な改善措置を規定していない時 は, 加工者は, 次の措置を講じなければならな
い.

（ア）少なくとも，問題となっているロットの 流通を許容できることを決定するための速 やかな評価が，適当な教育訓練を受けた か，またはこのような評価の経験を有する 者によって行われるまでは，影響を受けた 製品を隔離し，保留すること.

（イ）影響を受けた製品の流通を許容できるか 否かを決定するための評価を行うこと.な お，この評価は適当な教育訓練を受けた か, 又はこのような評価の経験を有する者 が行うこと.

（ウ）逸脱の結果，健康被害をむたらすものま たは品質の粗悪なものが流通経路に入って いないことを保証するために，必要があれ ば，影響を受けた製品に関して改善措置を 講じること.

（エ）逸脱の原因を改善するための改善措置を 講じること.

（オ）逸脱が再発するリスクを減らす上で, HACCP プランを改善する必要があるか否 かを決めるために，(10)の規定に適合する教 育訓練を受けた者による時を得たアセス メントを行うとともに, 必要があれば HACCP プランを改善すること.

エ すべての改善措置は文書にして記録に残すこ と、また，その記録は，検証に供され，記録の 維持保管の要件に従い, 維持管理されること.

(5) 検証

ア全体の検証

すべての加工者は, 合理的に起こりうる, 食 品衛生上の危害の発生を防止する上で適切な HACCP プランであることおよび当該プランが 効果的に実施されていることを検証すること. 検証事項としては，少なくとも次のことが含ま れていること.

（ア） HACCP プランの再評価

危害分析に影響を与えうるいかなる変更が 生じたとき, HACCP プランを変更した ときまたは少なくとも 1 年間に 1 度, HACCP プランの適切さを再評価すること. 危害分析に影響を与えうる変更とは，原材料 または原材料の入手先, 製品の組成, 加工方 法またはシステム, 最終製品の流通システ ム, あるいは最終製品の意図される使用法ま たは対象消費者の変更を含むむのであるこ と. 再評価は10の規定に適合する教育訓練を 受けた者によって行われること. 再評価に よって，当該プランがあはや(3)に規定された 要件を十分に満たさないことが明らかになっ 
た時は，速やかに改善すること。

（イ） HACCP 計画実施中の検証 次の事項を含むこと.

a 消費者からの苦情の評価：加工者が受理 した消費者からの苦情について，重要管理 点における管理状態に関係するか，または 未確認の重要管理点の存在を示唆するもの であるかを決定するため評価すること.

b 工程をモニタリングする機器 (計器) の キャリブレーション（校正）を行うこと.

c 必要に応じ，最終製品または中間製品の 検查を実施すること。

（ウ）記録の評価

110の規定に適合する教育訓練を受けた者に よる以下の事項に関する記録の評価を行い, サインおよび評価日時の記載を行うこと.

a 重要管理点のモニタリング

この評価の目的は, 最低限, 記録が完全 に行われていることを確認し，数值が管理 基準内に収まっていることを検証すること である.この評価は，記録してから 1 週間 以内に行うこと。

b 改善措置の実施記録

この評価の目的は，最低限，記録が完全 に行われていることを確認し，(3)才の規定 に基づく適切な改善措置が採られたことを 検証することである，この評価は，記録し てから 1 週間以内に行われること.

c 重要管理点におけるモニタリングに用い られる機器（計器）の校正記録

d 加工者の検証活動の一部である最終製品 または中間製品の検查記録

この評価の目的は，最低限，記録が完全 に行われていることおよびこれらの活動が 加工者の文書による検証手順に従って行わ れていることを確認することである。この 評価は, 記録してから正当な期間内に行わ れなければならない。

1 改善措置

消費者からの苦情の評価を含む検証手順によ り，改善措置を講じる必要性が明らかになった 時は，加工者は速やかに(4)の規定により適切な 改善措置を採らなければならない。

ウ 危害分析の再評価

危害分析に影響を与えることが生じた場合， 加工者は，再度，危害分析を行うこと，そのよ うな変更としては次のようなものが含まれる。 （ただし，限定するものではない）

（ア）原材料または原材料の入手先

（イ）製品の組成
（ウ）加工方法またはシステム

（エ）最終製品の流通システム

（オ）最終製品の意図される使用法または対象 消費者の変更

この再検討は110の規定に適合する教育訓 練を受けた者によって行われること.

\section{工 記録の維持保管}

工程のモニタリングに用いられる機器（計 器) の校正および定期的に行われる最終製品ま たは中間製品の検查の結果は, 文書にして, 記 録すること.

（6) 記録文書の維持管理システム

了一般的要件

本規則で求められているすべての記録は，次 のことが含まれていること.

（ア）加工者または輸入者の氏名（名称）およ び住所（所在地）

（イ）記録した行動（活動）が行われた日時

（ウ）記録した者のサインまたはイニシャル

（エ）適当であれば，製品の種類，製造コード 等製品を特定する事項. 加工その他の情報 は，観察の都度，記録すること。

1 記録の保存期間

（ア） 本規則で求められているすべての記録 は，要冷蔵の食品については，製造後少な くとも 1 年間, 冷凍および保存性のある食 品については，製造後少なくとも 2 年間, 加工施設または輸入者の米国内の事務所に おいて保管すること.

（イ）加工者が使用している機械設備または加 工工程の一般的な妥当性に関連した記録 （科学的な研究・評価の結果を含む）につ いては，加工施設において製造開始後少な くとも 2 年間は保管すること.

（ウ）むし，加工施設が季節的に長期間閉鎖さ れてしまう場合，あるいは加工船または遠 隔地のために記録の保管収容能力が限られ ている場合，記録は操業期間終了時に合理 的にアクセスできるその他の場所に移動す ることができるが, FDA の求めにより, 速 やかに戻すこと

ウ 公的な評価

本規則で求められているすべての記録および 本規則で求められているすべてのプランおよび 手順は，FDA の検查官が正当な時間に，検查 し，コピーできるあのであること.

工一般公開

本規則で求められているすべてのプランおよ び記録は，一般に公開することはできないもの であること. 
オコンピューター上の記録の維持管理

電子データの完全さおよびサインが確認さ れ，適当なコントロールが実施されているなら ば, 記録をコンピューター上で維持管理するこ とは認められる。

(7) HACCP プランへのサインとその日付の記載 ア HACCP プランは当該施設の長または製造管 理責任者によって，チェックを受け，その日付 とサインがされていること.このサインは, 企 業に打いて当該 HACCP プランが承諾された ことを意味するあのであること.

イ $\mathrm{HACCP}$ プランは, 次の時にはサインとその 日付が記載されていること.

（ア）最初の承諾時

（イ）修正が行われた時

（ウ）プランの検証が行われた時

8) その他の規則の適用を受ける製品

米国連邦規則 § 113 において「密封された容器 に容れられた低酸性の加熱食品」と定義される食 品および同規則 \&114において「酸性化食品」と 定義される食品であって，かつ本 HACCP 規則の 対象となる魚介類およびその加工品については, HACCP プランのなかに, 最終の気密性容器内に おけるボッリヌス毒素の産生に関する危害および そのコントロール方法を列挙する必要はないこ と.そのような魚介類およびその加工品の HACCP プランでは，その他の食品衛生上の危害 の発生防止策が含まれていること.

(9) 法律上の基礎

HACCP プランが必要であるにもかかわらず, HACCP プランを保持し，実施することができな い加工者または本規則の要件に従って操業してい ない加工者の製品は, 連邦食品医薬品化粧品法第 402(a) (4) の規定により, 品質の悪い粗悪品と見 なされなければならない. 加工者の行為が食品の 安全性を保証することに反していないかどうか は，当該加工者が HACCP プランを持つ必要があ る場合は，HACCP プランの全般的な実施状況を 評価することにより, 決定される.

(10)教育訓練については, 少なくと屯, 次のような 職務は, 魚介類およびその加工品への HACCP 原 則の適用に関し，FDAによって適当と承認され た標準化されたカリキュラムのあとで教育訓練を うけたのと同等の教育訓練を修了した者または仕 事の経験を通じ，それらの職務を果たすのに同等 の能力を身につけた者によって行われなければな らない，なお，教育訓練を受けた者は，加工者に 雇用された者である必要はない.

ア HACCP プランを作成すること.

1 HACCP プランを再評価し，修正すること。
ウ 記録の見直し，評価を行うこと。

(11) すべての加工者は，魚介類およびその加工品が 製造される各々の場所毎に, 衛生管理手順 (Sanitary Control Procedures) について，文書による Sanitation Standard Operation Procedures（衛 生標準作業手順書，以下「SSOP」という.）また は同様の文書を作成し，実施すべきである，加工 者は，SSOP のなかに，どのようにして衛生状態 を満たしていくのかについて，具体的かつ明確に 記載し，加工している施設および食品の両方が, 少なくとも Current GMP に規定された状態およ び取扱い要件に適合していることを保証するた め, 次の 8 項目について, 十分な頻度でモニタリ ングすること.

ア 製品に直接接触する水, 食品に直接接触する 面に使用される水，製水に使用される水の安全 性

イすべての食品に接触する機械器具の表面, 手 袋，および作業服の状態および清潔さ

ウ 不衛生な物体からの食品, 容器包装および食 品之直接接触するその他の表面（機械器具, 手 袋，作業着を含む）への污染ならびに原材料か ら加熱済みの製品への污染の防止措置

エ 手指の洗浄, 殺菌および便所の維持管理

才 食品, 容器包装および食品と直接接触するそ の他の表面を潤滑油, 燃料, 農薬, 洗剂, 殺菌 剂, 結露水, その他の化学的, 物理的および生 物学的污染物加ら防除する方法

力 有毒物質の適切な表示, 保管および使用方法

キ 食品, 容器包装および食品と直接接触するそ の他の表面の微生物学的な污染につながる従業 員の健康状態の管理

ク 食品加工施設からのそ族昆虫の排除

なお，加工者は，これらの状態および取扱い が適合しない場合は，適宜，改善措置を講じる こと.また，一般的衛生管理は， HACCP プラ ンの中に含めることもできるが，上記規定によ り適切にモニタリングが行われている限り，そ れらは HACCP プランの中に含める必要はな い.

(12) 輸入魚介類およびその加工品に関する特別の要 件

ア輸入者の検証

輸入者は検証活動を行うこと。また，定義に 規定した “加工者”に該当する場合は, HACCP プランを作成し，実施すること.

イ 各々の輸入者は次のいずれかを行うこと

（ア） 米国と同等または米国の検查システムに 
従って検査していること, 当該魚介類が検 查対象であること，サインをした当事者間 の現在の状況を正確に反映していることお よび検查システムは機能しており, そっく りそのまま施行されていることに関する有 効な覚え書きをFDA と交わしているかま たは同様の合意に達している国から魚介類 およびその加工品を輸入すること.

（イ）魚介類およびその加工品は本規則の要件 に従って加工されたものであることを保証 するための文書による検証手順を作成する こと. この手順には, 少なくとも, 次のこ とが含まれていること。

a 製品の規格

b 次のうちのいずれかを含む確認手段

(a) 輸入しようとしている特定のロットの 魚介類およびその加工品について, 本規 則で求められている HACCP および衛 生管理モニタリングの記録を輸出国の加 工者から入手する.

(b) 外国政府の検查担当部局または法的能 力のある第 3 者機関から, 輸入した魚介 類およびその加工品は本規則の要件に 従って加工されたあのであることを保証 する旨の証明書を連続的に，またはロッ 卜毎に入手する.

(c) 輸入した魚介類およびその加工品は本 規則の要件に従って加工されたものであ ることを保証するため, 外国の加工施設 を定期的に検查すること.

(d) 外国加工者の HACCP プランならび に輸入した魚介類およびその加工品は本 規則の要件に従って加工されたあのであ る旨の外国加工者加らの文書による保証 書（いずれも英文）のコピーのファイル を保管する.

（e）輸入した魚介類およびその加工品を定 期的に検查するとともに輸入した魚介類 およびその加工品は本規則の要件に従っ て加工されたあのである旨の外国加工者 からの文書による保証書（英文）のコ ピーのファイルを保管する.

(f) 本規則に規定された要件を満たしてい ることを同等のレベルで保証するその他 の適切な検証手順

ウ 法的能力のある第 3 者機関

輸入者は, イ(イ)に規定された検証活動の全 部または一部（輸入者を代表して輸入者の検証 手順を書くことを含む）を行わせるため，また は自ら行う際の援助を得るために法的能力のあ
る第 3 者機関を雇うことができる.

工 記録

輸入者は, イ(イ)に規定された確認手段の実 施およびその記録を文書にし，英文で保管しな ければならない。これらの記録は(6)の該当する 規定に適合していること.

才適合の決定

すべての輸入に供される魚介類およびその加 工品は, 本規則に従った条件のもとで加工され たことが証明されること。あし，輸入された魚 介類およびその加工品が本規則に基づき米国内 の加工者が求められていることと同等の条件の あとで加工された旨の証明がなければ，当該製 品は粗悪品と見なされ，輸入が認められない。

(13) 蕾煙および燯煙風味付け魚介類加工品に関する 個別要件

この種類の製品にとって，十分な管理が行われ ない場合, 最む起こりやすく重篤性の高い危害は ボッリヌスであるので，その HACCP プランに は，製品の品質保持期限をやや越える期間，製品 中におけるボッリヌス毒素の産生をゼロに抑える ための措置が含まれていること.

(14) 貝類に対する個別要件

了 貝類に由来するほとんどの危害のための最む 重要な防止的管理は貝類の採捕海域を適切に分 類し，コントロールすることである．それゆえ， 貝類の加工者の HACCP プランには，どのよう に採捕海域のコントロールを行うかが含まれて いること.

（ア） 貝類の管理当局 Shellfish Control Authority から承認された海域から採捕する

（イ）地方のライセンスの要件に適合した採捕 者から購入する

1 すべての殼付き貝は各々の容器に tag が添 付されていること. 当該 $\operatorname{tag} に は ，$ 採捕日，採 捕場所 (州名, 地名), 貝類の量と種類, 採捕者 の氏名, 採捕者の漁船の名称または登録番号, 貝類の管理当局から採捕者に発行された証明書 番号が記入されていること. バルクの殼付き貝 の場合は, タグの代わりに同様の情報が記載さ れた積み荷申告書が添付されていること.

ウむき身の貝の容器すべてには，包装者または 再包装者の名前, 重量および証明書番号が記載 されたラベルが添付されていること.

\section{3. 原材料における HACCP の適用例（養殖えび）}

原材料となる水産物を HACCP システムにより管理 している具体的な例として, タイの漁業省が実施してい る養殖エビの品質改善プロジェクトの例を紹介した。こ れは, Asean-Canada Fisheries Post-Harvest Technol- 
ogy Project（カナダ政府による Asean 諸国に対する技 術援助）のもと，カナダ漁業省とタイの漁業省が行った パイロットプロジェクトの内容を同 Project の End of Project Conference において発表されたものを本人の 承諾を得て，紹介したものである。

(1) プロジェクトの目的

(1) ブラックタイガーエビ養殖段階における取扱い とエビの品質の関係に関する情報の収集

(2) 業界が直面している品質および安全性の問題点 を解決すること

（3）官能検查および微生物検查の技術を開発するこ と

(4) 残留抗菌性物質を検出する技術を開発すること

(5)エビの養殖場および処理場における HACCP プランのモデルを作成すること

(6) プロジェクトの結果得られた成果を営業者に対 するトレーニングを通じて還元すること

（2）モデル HACCP プランの作成 1一危害の原因物質 の特定

危害分析の結果，食品衛生上の危害の原因物質と しては, 原料エビの病原微生物（サルモネラ, ビブ リオ等）および腐敗微生物，養殖池の水由来の微生 物, 動物用医薬品の残留等が考えられた。

(3) 養殖池における HACCP の具体例

$\mathrm{CCP}$ としては, (1)エビの養殖開始時の稚エビの 選定，(2)使用水の管理，(3)養殖時の水質管理，(4)動 物用医薬品の使用時が考えられた.ここにおける管 理基準としては，それぞれの CCP 毎に(1)稚エビの 確認，(2)水質基準，(3)換水頻度，(4)動物用医薬品の 使用時期，量の確認が考えられた。

モニタリングの方法としては，それぞれの CCP 毎に(1)稚エビの官能検查, (2)水質検査, (3)換水頻度 の確認，(4)動物用医薬品の使用時の正確な記録之当 該記録の確認が考えられた。

（4）処理場における HACCP の具体例

CCP としては，処理場における受入工程が考え られ, 管理基準としては, 新鮮さ (官能検查), 温度 が 0 から $5^{\circ} \mathrm{C}$ の範囲内であることおよび池で採捕 してからX 時間以内に到着したこと，残留抗菌性 物質が検出されないことなどが考えられた.

モニタリングの方法としては，ブラックタイガー の腐敗パターンを明らかにした上で，標準品と試験 サンプルとを比較すること，温度の測定および原料 エビに添付された荷送り表から生産者, 養殖池を確 認した上で記載された採捕時間と処理場への到着時 間から管理基準に規定された時間以内であることを 確認することならびにバイオアッセイとHPLCに より抗生物質および合成抗菌剤（オキソリン酸）の 残留がないことを確認することが考えられた。この モニタリングは，池毎に実施し，検査結果が明らか
になるまで当該原料エビを冷蔵保管するか，または 製造・加工は開始するが，バッチコントロールを徹 底し，仮に製造加工途中で管理基準に適合しないこ とが明らかになった場合には，仕掛品を含め，当該 ロットを排除する改善措置を講じるかがいずれかが 考えられた。

(5) 監視技術

モニタリングとしては，(3),(4) に記載した比較的 短時間に結果が得られる官能検查，理化学検查等を 用いることになる。例えば，危害の原因物質の一つ であるサルモネラを池毎に検査し，迅速に結果を得 るのは難しいため, 到着時の新鮮さ, 温度および採 捕からの時間で管理し，一定の範囲内であれば，サ ルモネラの菌数が許容範囲内に収まるということを あらかじめ確認した上で，モニタリングを実施する ことになる．当然，モニタリングの効果を確認する ための検証方法としては，一定頻度でサルモネラの 污染レベルを検査で確認することが必要となる。

(6) 業界に対するトレーニング

このプロジェクトの実施のためには，施設毎にモ ニタリング担当者のトレーニングが必須となる，実 際には，処理場受入時の官能検查において新鮮なエ ビを見分けるトレーニング，残留抗菌性物質の検査 に関するトレーニング (バイオアッセイ, HPLC), 水質検查業界に関するトレーニング，HACCP の実 施に関するトレーニングが行われ，合計 200 人の製 造および $\mathrm{QC}$ 担当者が参加した。これらの営業者に 対するトレーニングは，カナダ漁業省の専門家を招 聘し，行われたが，同時にタイ漁業省の担当者に対 するトレーニングあ行われ，日常の養殖池および処 理場に対する監視指導に生かされた。

(7) 成果

このプロジェクトの成果としては，養殖業者向け に養殖エビ品質管理マニュアルが作成され，その実 施状況について，タイ漁業省の検查官によって チェックリストを用いた監視が行われるようになっ たこと，いくつかの処理場において，残留抗菌性物 質の検査体制が整備され，エビの受入時に池毎に検 查することが可能になったことなどが挙げられる.

タイ国産のエビについては, 1990 年以来, 我が 国での輸入時，テトラサイクリン系抗生物質とオキ ソリン酸の残留事例が見られたことから，輸入時に 全ロット検查（現在では検查命令）が行われていた が，1996 年から，残留防止対策が整備された処理 場については夕イ国政府の保証のもと，検査命令の 対象から除外する措置がとられている。これあ本プ ロジェクトの成果の一部といえよう。このように, 本プロジェクトが進んでいくとともに，カナダ，米 国，日本およびその他の国々に対する輸出量が増加 するという大きな成果む得られたとのことである。 


\section{4.おわりに}

現在, $\mathrm{EC}$, 米国に水産食品を輸出するためには, 原則 として欧州委員会の DG XXIV および米国FDA と協議 し，輸出国の衛生管理体制が EC または米国のそれと同 等であることを確認する作業が必要となる．このような 動きを受けて, 最近, 水産食品の衛生検查の同等性の評 価, あるいは水産食品の規格基準の同等性の評価の問題 が国際会議で頻繁に議論されようとしている. 今後, 我 が国の水産食品の衛生管理においても，このような国際 的な動向を踏まえながら， GMP および HACCP の導入 を進める必要があろう。

\section{文献}

1) EC Directive 91/493: Laying down the health conditions for the production and the placing on the market of fishery products $(91 / 493 / \mathrm{EEC})$.

2) EC Directive 91/492: Laying down the health conditions for the production and the placing on the market of live bivalve molluscs (91/492/EEC).

3) 21 CFR Part 123: FISH AND FISHERY PRODUCTS, Federal Register, Vol. 60, p. 242, 65197-65202. 